\title{
Desensitization of Human $\mathrm{CRF}_{2(\mathrm{a})}$ Receptor Signaling Governed by Agonist Potency and $\beta$ Arrestin2 Recruitment
}

\author{
Richard L. Hauger ${ }^{1,2,{ }^{*}}$, J. Alberto Olivares-Reyes ${ }^{3}$, Sandra Braun ${ }^{2}$, Judith Hernandez- \\ Aranda $^{3}$, Christine C. Hudson ${ }^{4}$, Eric Gutknecht ${ }^{5,6}$, Frank M. Dautzenberg ${ }^{5, * \star}$, and Robert $\mathbf{H}$. \\ Oakley $^{7}$ \\ ${ }^{1}$ Center of Excellence for Stress and Mental Health, San Diego VA Healthcare System, $3350 \mathrm{La}$ \\ Jolla Village Drive, San Diego, CA 92161, USA \\ ${ }^{2}$ Department of Psychiatry, School of Medicine, University of California, San Diego, 9500 Gilman \\ Drive, La Jolla, CA 92093, USA \\ ${ }^{3}$ Department of Biochemistry, Center for Research and Advanced Studies of the National \\ Polytechnic Institute (CINVESTAV-IPN), A.P. 14-740, Mexico, D.F. 07360, Mexico \\ ${ }^{4}$ Xsira Pharmaceuticals, Inc., 7030 Kit Creek Road, Morrisville, NC 27560, USA \\ ${ }^{5}$ CNS Research, Johnson \& Johnson Research \& Development, Turnhoutseweg 30, Beerse, \\ Belgium \\ ${ }^{6}$ Department of Molecular and Biochemical Pharmacology, Institute for Molecular Biology and \\ Biotechnology, Vrije Universiteit Brussel (VUB), Pleinlaan 2, B-1050 Brussel, Belgium \\ ${ }^{7}$ Laboratory of Signal Transduction, National Institute of Environmental Health Sciences, National \\ Institutes of Health, 111 TW Alexander Drive, Research Triangle Park, NC 27709, USA
}

\section{Abstract}

The primary goal was to determine agonist-specific regulation of $\mathrm{CRF}_{2(\mathrm{a})}$ receptor function. Exposure of human retinoblastoma Y79 cells to selective (UCN2, UCN3 or stresscopins) and nonselective (UCN1 or sauvagine) agonists prominently desensitized $\mathrm{CRF}_{2(a)}$ receptors in a rapid, concentration-dependent manner. A considerably slower rate and smaller magnitude of desensitization developed in response to the weak agonist $\mathrm{CRF}$. $\mathrm{CRF}_{1}$ receptor desensitization stimulated by CRF, cortagine or stressin1-A had no effect on $\mathrm{CRF}_{2(a)}$ receptor cyclic AMP signaling. Conversely, desensitization of $\mathrm{CRF}_{2(a)}$ receptors by UCN2 or UCN3 did not crossdesensitize Gs-coupled $\mathrm{CRF}_{1}$ receptor signaling. In transfected HEK293 cells, activation of $\mathrm{CRF}_{2(a)}$ receptors by UCN2, UCN3 or CRF resulted in receptor phosphorylation and internalization proportional to agonist potency. Neither protein kinase A nor casein kinases mediated $\mathrm{CRF}_{2(\mathrm{a})}$ receptor phosphorylation or desensitization. Exposure of HEK293 or U2OS cells to UCN2 or UCN3 (100 nM) produced strong ßarrestin2 translocation and colocalization with membrane $\mathrm{CRF}_{2(\mathrm{a})}$ receptors while $\mathrm{CRF}(1 \mu \mathrm{M})$ generated only weak $\beta$ arrestin2 recruitment. $\beta$ arrestin2 did not internalize with the receptor, however, indicating that transient $\mathrm{CRF}_{2(\mathrm{a})}$

\footnotetext{
*Corresponding author: Richard L. Hauger, M.D., Department of Psychiatry, University of California, San Diego, 9500 Gilman Drive, La Jolla, CA 92093-0603, USA; Telephone: 858-552-7590; FAX: 760-634-0597; rhauger@ucsd.edu. * Current address: Nycomed GmbH, Byk-Gulden-Strasse 2, D-78467 Konstanz, Germany

Publisher's Disclaimer: This is a PDF file of an unedited manuscript that has been accepted for publication. As a service to our customers we are providing this early version of the manuscript. The manuscript will undergo copyediting typesetting, and review of the resulting proof before it is published in its final citable form. Please note that during the production process errors may be discovered which could affect the content, and all legal disclaimers that apply to the journal pertain

Conflict of Interest

The authors have no conflict of interest to report.
} 
receptor-arrestin complexes dissociate at or near the cell membrane. Since deletion of the ßarrestin2 gene upregulated Gs-coupled $\mathrm{CRF}_{2(a)}$ receptor signaling in MEF cells, a $\beta$ arrestin2 mechanism restrains Gs-coupled $\mathrm{CRF}_{2(\mathrm{a})}$ receptor signaling activated by urocortins. We further conclude the rate and extent of homologous $\mathrm{CRF}_{2(\mathrm{a})}$ receptor desensitization are governed by agonist-specific mechanisms affecting GRK phosphorylation, ßarrestin2 recruitment, and internalization thereby producing unique signal transduction profiles that differentially affect the stress response.

\section{Introduction}

Hypothalamic-pituitary-adrenal (HPA) axis, defensive behavior, autonomic, metabolic, immune, and cardiovascular responses during stress and trauma are coordinated by the interplay of neuronal corticotropin releasing factor (CRF) and urocortin peptides (UCN1, $\mathrm{UCN} 2$, UCN3) differentially binding to and activating CRF receptors type $1\left(\mathrm{CRF}_{1}\right)$ and type $2\left(\mathrm{CRF}_{2}\right)$, which are members of the class $\mathrm{B} 1$ group of the $\mathrm{G}$ protein-coupled receptor (GPCR) superfamily [1-7]. Both CRF receptors are capable of signaling via the protein kinase A (PKA), protein kinase C (PKC), extracellular signal-regulated kinase (ERK) mitogen-activated protein (MAP) kinase, protein kinase B (Akt), and other pathways, although the dominant mode of signal transduction is coupling to $G$ protein subunit Gsa and activating adenylyl cyclase to generate adenosine 3',5'-cyclic monophosphate (cyclic AMP) [1-7]. $\mathrm{CRF}_{1}$ receptor signaling generates critical defensive behaviors, HPA hormone secretion, and physiological responses required to survive trauma and stress [1-12]. Behavioral actions mediated by the $\mathrm{CRF}_{2}$ receptor are complex and contingent upon the brain site and activating agonist unlike the $\mathrm{CRF}_{1}$ receptor [1,6-9]. Emerging evidence indicates, however, forebrain $\mathrm{CRF}_{2}$ receptor signaling can be anxiogenic depending on the intensity and duration of the stress state [1,9-11]. These CRF receptor-mediated processes must be rapidly initiated in order to meet physiological demands essential for survival. Counter-regulation to restore homeostasis is equally important, however, to prevent stressinduced psychiatric and medical illnesses developing from the detrimental effects of abnormal CRF receptor signaling.

Transduction of cellular signals by G protein-coupled receptors (GPCRs) is stringently regulated to prevent the deleterious effects of unrestrained GPCR signaling. The rapid termination of signaling mediated by agonist-occupied GPCRs is referred to as homologous desensitization and involves the following: (i) Agonist-activated receptors selectively recruit a G protein-coupled receptor kinase (GRK) that phosphorylates particular serines and/or threonines in the receptor's intracellular loops or carboxyl-terminus (C-terminus). (ii) Phosphorylated receptors attract cytoplasmic $\beta$ arrestins to the cell membrane where they bind to receptors, uncoupling them from their cognate $\mathrm{Ga}$ via competition and steric hindrance. (iii) Barrestins subsequently target the receptors to clathrin-coated pits for endocytosis by interacting with clathrin and clathrin adapter protein AP-2. Internalized receptors are either sorted for dephosphorylation and recycling back to the plasma membrane or trafficked into lysosomes for degradation. [13-15]. The stability of the receptor- $\beta$ arrestin interaction distinguishes two classes of GPCRs, termed class A and class B [15]. Class A GPCRs form transient complexes with $\beta$ arrestin that dissociate at or near the plasma membrane after the receptor are directed to clathrin coated pits and consequently internalize without $\beta$ arrestin. Class B receptors form stable complexes with $\beta$ arrestins that internalize as a unit into endocytic vesicles and persist inside the cell. The stability of the receptor- $\beta$ arrestin interaction appears to regulate the rate receptors resensitize as well as the spatial-temporal pattern of ßarrestin-dependent signaling pathways [14,15]. 
Recently, $\beta$ arrestins have been shown to contribute to desensitization and internalization of the $\mathrm{CRF}_{1}$ and $\mathrm{CRF}_{2(\mathrm{~b})}$ receptors, the peripherally expressed splice variant of the $\mathrm{CRF}_{2}$ receptor [16]. There is no information, however, about the homologous regulation of the centrally expressed $\mathrm{CRF}_{2(\mathrm{a})}$ receptor signaling by phosphorylation, $\beta$ arrestin recruitment, and internalization mechanisms. Since abnormal signaling by both CRF receptors in the extended amygdala and forebrain may contribute to the pathophysiology of human stress, anxiety, and depressive disorders, understanding control of $\mathrm{CRF}_{2}$ receptor function could provide important insight into the pathogenesis of posttraumatic stress disorder and affective illnesses.

Thus, the primary goal of this study was to investigate the desensitization profile of $\mathrm{CRF}_{2(\mathrm{a})}$ receptors following exposure to a variety of physiological ligands. We looked not only at the desensitization of cyclic AMP signaling by the $\mathrm{CRF}_{2 \text { (a) }}$ receptor but also at three primary components of the desensitization process: (i) agonist-stimulated phosphorylation, (ii) $\beta$ arrestin recruitment, and (iii) receptor internalization. In addition, because we have recently shown that $Y 79$ cells co-express both $\mathrm{CRF}_{1}$ and $\mathrm{CRF}_{2(\mathrm{a})}$ receptors [17], we were able to study potential regulatory interactions between $\mathrm{CRF}_{1}$ and $\mathrm{CRF}_{2(\mathrm{a})}$ receptors in an endogenous setting. Results from our study reveal that desensitization of Gs-coupled $\mathrm{CRF}_{2(\mathrm{a})}$ receptor signaling is unaffected by $\mathrm{CRF}_{1}$ receptor activity and the serine-threonine kinases, protein kinase $\mathrm{A}$ and casein kinases, but strongly dependent on agonist potency and $\beta$ arrestin2 recruitment.

\section{Methods and Materials}

\subsection{Reagents}

Reagents for cell biology experiments were obtained from the following sources: (1) bovine serum albumin (BSA, fraction V), isobutylmethylxanthine (IBMX), and other highly purified chemicals from Sigma (St. Louis, MO); (2) aprotinin (Trasylol) from Calbiochem (San Diego, CA); (3) forskolin, PKA activators (dbcAMP, SpcAMP-S), PKA inhibitors (H89, RpcAMP-S), and casein kinase inhibitors (TBB, quinalizarin, IC261) from Calbiochem (San Diego, CA); (4) defined fetal bovine serum (\#SH30070.03) from Hyclone (Logan, UT). The UCSD Cell Culture Core Facility supplied all other cell culture reagents (Mediatech-CELLGRO). The following CRF receptor agonists were purchased from Bachem (Torrance, CA; purity > 98\%) or Phoenix (Belmont, CA; purity >98\%) to stimulate cyclic AMP accumulation, and/or to desensitize $\mathrm{CRF}_{1}$ or $\mathrm{CRF}_{2}$ receptors: ovine $\mathrm{CRF}$ (oCRF); sauvagine (SVG); human/rat CRF (h/rCRF); human urocortin 1 (UCN1), urocortin 2 (UCN2), and urocortin 3 (UCN3); and human stresscopin (SCP) and stresscopin-related peptide (SRP). Drs. Aaron Hsueh and Teddy Hsu (Stanford University) kindly provided stresscopin peptides for the initial experiments. All SDS-PAGE reagents were purchased from Invitrogen-NOVEX (Carlsbad, CA). For $\mathrm{CRF}_{1}$ receptor phosphorylation experiments, the following reagents were used: (1) protein A sepharose (PrA-Seph) from Oncogene Research Products (Cambridge, MA); (2) the mouse monoclonal anti-HA (HA.11) antibody for immunoprecipitation, the FITC-labeled HA. 11 antibody (\#FITC-101L) for flow cytometry in transfected HEK293 cells from BAbCO/Covance (Emeryville, CA); (3) the Alexa Fluor 488-labeled HA.11 antibody (\#A488-101L) for flow cytometry in transfected $\mathrm{MEF}$ cells from BAbCO/Covance (Emeryville, $\mathrm{CA}$ ).

\subsection{Plasmid cDNAs}

The human $\mathrm{CRF}_{2(a)}$ receptor was previously amplified from a human retinoblastoma Y79 cell complementary DNA (cDNA) library by PCR and subcloned into pcDNA3 (Invitrogen, San Diego, CA) using KpnI and $X b a I$ sites [18]. The influenza hemagglutinin (HA) epitope tag (YPYDVPDYA) was inserted between residues $\mathrm{Ala}^{17}$ and $\mathrm{Glu}^{18}$, which is an inert 
region of the amino-terminus (N-terminus) [19], using oligo-directed mutagenesis (Quick Change $^{\mathrm{TM}}$ kit, Stratagene, La Jolla, CA). Cyclic AMP signaling by HA-tagged and wild-type $\mathrm{CRF}_{2(a)}$ receptor were similar (data not shown). Construction of the ßarrestin2-green fluorescent protein (GFP) expression vector has been described previously [15]. Sequences of cDNA constructs were confirmed using single-stranded DNA sequencing.

\subsection{Cell culture and transfection}

Suspension human retinoblastoma Y79 cultures were grown at a density of $2 \times 10^{7}$ cells/flask in RPMI-1640 and used between passages $4-25$ as previously described $[17,20]$. Human embryonic kidney HEK293 cells were transfected with the cDNA encoding the HA-tagged human $\mathrm{CRF}_{2(a)}$ receptor as previously reported [18]. Cyclic AMP signaling experiments confirmed that the sensitivity (i.e., half-maximal effective concentration, $\mathrm{EC}_{50}$ ) and maximum for agonist-stimulated cyclic AMP accumulation were not altered by insertion of the HA epitope tag in the $\mathrm{CRF}_{2(\mathrm{a})}$ receptor's $\mathrm{N}$-terminus (data not shown). Likewise, the binding affinity of the $\mathrm{CRF}_{2(a)}$ receptor for its agonists was also not altered by tagging the $\mathrm{CRF}_{2}$ (a) receptor with the HA epitope (data not shown). For phosphorylation experiments, transiently transfected HEK293 cells were seeded at $6 \times 10^{5}$ cells/10-cm dish in DMEM containing 10\% (v/v) FBS, $100 \mu \mathrm{g} / \mathrm{ml}$ streptomycin, $100 \mathrm{IU} / \mathrm{ml}$ penicillin. For confocal microscopy, HEK293 cells were cultured and transiently transfected as previously described [21]. For quantification of $\beta$ arrestin-GFP translocation, human osteosarcoma U2OS cells (American Type Culture Collection) were cultured in MEM supplemented with 10\% (vol/ vol) heat-inactivated fetal bovine serum, $10 \mathrm{mM}$ HEPES, $2 \mathrm{mM} \mathrm{L}$-glutamine, and $10 \mu \mathrm{g} / \mathrm{ml}$ gentamicin [21]. For other experiments, wild-type (expressing both $\beta$ arrestins) and ßarrestin2 knockout mouse embryonic fibroblast (MEF) cell lines derived from wild-type and $\beta$ arrestin2 knockout mice were cultured as previously described [22], and transiently transfected with human $\mathrm{CRF}_{2(\mathrm{a})}$ receptor pcDNA3 using a Amaxa Biosystems Nucleofector II and following established Amaxa protocols (Amaxa-Lonza Cologne, Walkersville, MD). Transfection efficiency was assessed by co-transfecting pmaxGFP and measuring \% fluorescence of cellular GFP protein expression. GFP fluorescence was similar in transfected HEK293 cells $(55.4 \pm 2.2 \%)$ and transfected MEF cells $(55.9 \pm 1.8 \%)$.

\subsection{Agonist-stimulated cyclic AMP accumulation experiments and cyclic AMP radioimmunoassay method}

Following extensive cell washing, intracellular cyclic AMP levels were measured in nonacetylated cell lysates using a double-antibody radioimmunoassay kit (cyclic AMP $\left[{ }^{125} \mathrm{I}\right]$ assay system, RPA 509; Amersham International, Little Chalfont, UK), as previously described [17,20]. In addition to UCN2 and UCN3 [2], stresscopin (SCP) and stresscopinrelated peptide (SRP) are also selective $\mathrm{CRF}_{2}$ receptor agonists [23]. In Y79 cells, concentration-response curves $(0-100 \mathrm{nM})$ comparing intrinsic agonist activities showed that the sensitivity $\left(\mathrm{EC}_{50}\right)$ and maximum for cyclic $\mathrm{AMP}$ accumulation stimulated by urocortin 2 (Figure 1) and SRP were similar as were the $\mathrm{EC}_{50}$ and maximum for cyclic AMP accumulation stimulated by UCN3 and SCP (Hauger \& Dautzenberg, unpublished data). Although the maximum values for cyclic AMP accumulation stimulated by UCN2 and UCN3 were comparable in recombinant HEK293 and SK-N-MC cells stably expressing $\mathrm{CRF}_{2 \mathrm{a}}$ receptors, the $\mathrm{EC}_{50}$ for UCN2 was lower (i.e., higher sensitivity) than that for UCN3 in stably transfected HEK293 and human neuroblastoma SK-NMC cells [18], and in Y79 cells [17]. Thus, human UCN2 was used to stimulate cyclic AMP accumulation in Y79 cells in the majority of experiments.

\subsection{Confocal microscopy}

HEK293 cells expressing the non-epitope-tagged $\mathrm{CRF}_{2}$ receptor and $\beta$ arrestin2-GFP were plated on 35-mm glass bottom culture dishes (MatTek, Ashland, MA) and cultured 
overnight using a previously published protocol $[15,24]$. One hour before the experiment, the medium was removed and replaced with serum- and phenol red-free medium supplemented with $10 \mathrm{mM}$ HEPES. Confocal microscopy was performed on a Zeiss laser scanning microscope. Images were acquired from live cells in real time before and after agonist addition using single excitation $(488 \mathrm{~nm})$. For colocalization experiments, live HEK293 cells expressing HA-tagged $\mathrm{CRF}_{2(a)}$ receptors and $\beta$ arrestin2-GFP were incubated with an anti-HA mouse monoclonal antibody conjugated to Alexa Fluor 594 (Invitrogen, San Diego, CA) at $37^{\circ} \mathrm{C}$ for $45 \mathrm{~min}$ in serum- and phenol red-free medium supplemented with $10 \mathrm{mM}$ HEPES. Cells were then washed with this medium and evaluated by confocal microscopy. Images were collected sequentially using dual excitation (488 $\mathrm{nm}$ from argon laser, $543 \mathrm{~nm}$ from HeNe laser) and emission filter sets (band pass, $500-530 \mathrm{~nm}$; long pass $560 \mathrm{~nm}$ ) from live cells in real time before and after agonist addition.

\subsection{Quantification of $\beta$ arrestin2-GFP translocation}

Translocation of $\beta$ arrestin2-GFP was quantified as described previously [21]. In brief, U2OS cells transiently expressing $\mathrm{CRF}_{2(a)}$ receptor and $\beta$ arrestin2-GFP were seeded $24 \mathrm{~h}$ posttransfection at 15,000 cells per well in 96-well black ViewPlates (\#6005182; PackardPerkinElmer, Waltham, MA). U2OS cells were employed over HEK293 cells for their superior adherence properties and image quality [25]. After an overnight incubation at $37^{\circ} \mathrm{C}$, the media was removed and replaced with $100 \mu \mathrm{L}$ of phenol-red-free MEM with $10 \mathrm{mM}$ HEPES and $2 \mathrm{mM} \mathrm{L-glutamine} \mathrm{for} \mathrm{a} 45$-minute incubation at $37^{\circ} \mathrm{C}$. Cells were stimulated for $30 \mathrm{~min}$ at $37^{\circ} \mathrm{C}$ with various concentrations of $\mathrm{UCN} 2, \mathrm{UCN} 3$, or vehicle. The cells were then fixed and nuclei stained by addition of $120 \mu \mathrm{L}$ of $4 \% \mathrm{v} / \mathrm{v}$ formaldehyde in PBS and 5 $\mu \mathrm{g} / \mathrm{ml}$ Hoechst nuclear stain. After a 45-min incubation, the fixative and nuclear stain were removed and replaced with $200 \mu \mathrm{L}$ PBS. The INCell Analyzer 3000 (GE Healthcare Biosciences, Piscataway, NJ), a laser-based, confocal imaging system, was employed to quantitate the $\beta$ arrestin2-GFP translocation response, as described previously $[25,26]$. In brief, images were quantified using the granularity analysis GRN1 algorithm that identifies fluorescent spots or grains of ßarrestin2-GFP localization based on size and fluorescence intensity. A grain size setting of 5 and an intensity gradient setting of 1.25 were employed for this analysis. Only GFP-positive cells, selected using a cell intensity signal threshold of 100 , were quantitated. The reported parameter "Fgrains" represents the average fluorescence intensity of the spots or grains of ßarrestin2-GFP localization.

\subsection{Receptor phosphorylation assay}

Phosphorylation of the $\mathrm{CRF}_{2}$ receptor was measured using a previously published method for determining $\mathrm{CRF}_{1}$ receptor phosphorylation [21,27]. Briefly, transfected HEK293 cells in 10-cm dishes were metabolically labeled for $4 \mathrm{~h}$ at $37^{\circ} \mathrm{C}$ in $5 \mathrm{ml}$ of $\mathrm{P}_{\mathrm{i}}$-free DMEM containing $0.1 \%(w / v) ~ B S A$ and $100 \mu \mathrm{Ci} / \mathrm{ml}^{32} \mathrm{P}_{\mathrm{i}}$. Cells were then treated with vehicle or 100 $\mathrm{nM}$ urocortin 2 for $10 \mathrm{~min}$. In protein kinase $\mathrm{A}$ and casein kinase experiments, cells were pretreated for 30 min with PKA inhibitors (H89, RpcAMP) or a CK inhibitor (TBB) prior to agonist stimulation. After cells were lysed in lysis buffer (LB: $50 \mathrm{mM}$ Tris, $\mathrm{pH} 8.0,100 \mathrm{mM}$ $\mathrm{NaCl}, 20 \mathrm{mM} \mathrm{NaF}, 10 \mathrm{mM}$ Na pyrophosphate, $5 \mathrm{mM}$ EDTA, $10 \mathrm{mg} / \mathrm{ml}$ aprotinin, $10 \mu \mathrm{g} / \mathrm{ml}$ leupeptin, $10 \mu \mathrm{g} / \mathrm{ml}$ soybean trypsin inhibitor, $10 \mu \mathrm{g} / \mathrm{ml}$ pepstatin, $10 \mu \mathrm{g} / \mathrm{ml}$ benzamidine, 1 mM PMSF, $1 \mu \mathrm{M}$ okadaic acid), they were pre-extracted by addition of LB containing $2 \mathrm{M}$ $\mathrm{NaCl}$ and $8 \mathrm{M}$ urea followed by overnight tumbling at $4^{\circ} \mathrm{C}$. Membranes were then solubilized in LB supplemented with $1 \%$ (v/v) NP 40, $1 \%$ (w/v) Na deoxycholate and $0.1 \%$ $(w / v)$ SDS. After clarification at $14,000-\mathrm{g}$, solubilized membranes were pre-cleared by being incubated with $2 \%(\mathrm{v} / \mathrm{v})$ protein A sepharose for $1 \mathrm{~h}$ at $4^{\circ} \mathrm{C}$. Immunoprecipitation of HA-tagged $\mathrm{CRF}_{2(a)}$ receptors was performed by adding a high affinity HA antibody ( $\left.1 \mu \mathrm{l}\right)$ and $2 \%(\mathrm{v} / \mathrm{v})$ protein A sepharose followed by incubation overnight at $4{ }^{\circ} \mathrm{C}$. After washing of the sepharose-bound immune complexes in LB+ lacking protease inhibitors, ${ }^{32} \mathrm{P}$-labeled 
phospho- $\mathrm{CRF}_{2}$ receptors were eluted in Laemmli sample buffer for $1 \mathrm{~h}$ at $48^{\circ} \mathrm{C}$ and resolved by SDS-PAGE (10\% resolving gel) after loading equal amounts of protein in each lane.

\subsection{Flow cytometry receptor internalization assay}

HEK293 transiently expressing the HA-tagged $\mathrm{CRF}_{2(a)}$ receptor were plated in 6-well plates and incubated overnight. Afterward, the cells were incubated with UCN2, UCN3, or h/rCRF $(100 \mathrm{nM})$ or media (control) for $60 \mathrm{~min}$ and receptor sequestration was assessed by flow cytometry using a FACS Canto as described previously [21]. Specificity of the receptor internalization signal detected by the FITC-labeled HA.11 monoclonal antibody (Covance Research Products: Denver, PA; \#FITC-101L) was verified by demonstrating that cells transfected with empty vector exhibited very low immunostaining. In addition, no appreciable immunostaining of $\mathrm{HA}$-tagged $\mathrm{CRF}_{2(\mathrm{a})}$ receptor-expressing cells was measured using a FITC-labeled IgG to detect nonspecific binding. Gating was performed only on single live cell populations.

\subsection{Data reduction and statistical analyses}

Data reduction and statistical analyses were performed with PRISM ${ }^{\mathrm{TM}}$, Version 6.0c program for Mac OS X (GraphPad Software, San Diego, CA). Cyclic AMP levels (pmoles/ 10 cells) measured by RIA were calculated using a log-logit program. Cyclic AMP data are presented as mean \pm SEM for basal (buffer) and agonist-stimulated levels, except for Figure 5B, Figure 8C, and supplementary Table 2 where \%Control was calculated after subtracting the basal level for the pretreatment condition. $\mathrm{EC}_{50}$ (sensitivity) and maximum values were calculated from the full concentration-response curves for agonist stimulation $(0-1 \mu \mathrm{M})$ of cyclic AMP accumulation (Figure 1) and Barrestin2 GFP translocation (Figure 12).

Statistical analyses were done using one- or two-way analyses of variance (ANOVAs), depending on the experimental design, to determine significance within and across experimental groups. When statistically appropriate and indicated, planned analyses were performed using Bonferroni's multiple comparison tests to determine significant differences between individual groups. $\mathrm{CRF}_{2(\mathrm{a})}$ receptor phosphorylation bands were imaged, quantitated and analyzed using our previously published method [21]. Flow cytometry data was analyzed by the DIVA software (version 6.1.2).

\section{Results}

\subsection{Time- and concentration-dependence of homologous desensitization of $\mathrm{CRF}_{2}$ receptors induced by urocortin 2 , urocortin 3, and stresscopins}

The time-dependent desensitization of $\mathrm{CRF}_{2(a)}$ receptors is significantly less $(\mathrm{p}<0.001)$ in magnitude following exposure of human retinoblastoma Y79 cells to a saturating concentration of UCN3 (100 nM) for $5 \min$ (34.4\% decrease), $15 \min$ (40.7\% decrease), 30 $\min (61.2 \%$ decrease), or $1 \mathrm{~h}$ ( $66.9 \%$ decrease) compared to the $\sim 90 \%$ desensitization of cyclic AMP signaling resulting from $100 \mathrm{nM} \mathrm{UCN} 2$ pretreatment at the same time points [17]. Since $\mathrm{UCN} 2$ is a more potent ligand than $\mathrm{UCN} 3$ at $\mathrm{CRF}_{2(a)}$ receptors $[2,17,18]$, the more rapid and greater desensitizing action of $\mathrm{UCN} 2$ compared to $\mathrm{UCN} 3$ on $\mathrm{CRF}_{2(a)}$ receptors is consistent with the concept that stronger agonists can increase the rate and magnitude of homologous GPCR desensitization [28].

To further characterize homologous $\mathrm{CRF}_{2(a)}$ receptor desensitization, we performed concentration-response curves for the stimulation of cyclic AMP accumulation following a 30-min agonist pretreatment, which is the time point of maximal $\mathrm{CRF}_{2(\mathrm{a})}$ receptor desensitization [17]. Pretreatment of Y79 cells with a saturating concentration of UCN2 or UCN3 significantly decreased the maximum for UCN2-stimulated cyclic AMP accumulation $\sim 65 \%$ and $\sim 50 \%$, respectively, compared to control cells (Figure 1, 
supplementary Table 1). In addition, the sensitivity $\left(\mathrm{EC}_{50}\right)$ of UCN2-stimulated cyclic AMP accumulation was shifted to the right following $\mathrm{CRF}_{2(a)}$ receptor desensitization induced by either agonist, however this effect was only significant for UCN2 pretreatment (supplementary Table 1). We next investigated the concentration-dependent characteristics of UCN2- or UCN3-induced $\mathrm{CRF}_{2(a)}$ receptor desensitization. The maximum response for UCN2-stimulated cyclic AMP accumulation progressively decreased in cells pretreated with all UCN2 concentrations ranging from $1 \mathrm{nM}$ to $1 \mu \mathrm{M}$ ( $\mathrm{p}<0.001$ ) (Figure $2 \mathrm{~A})$. In contrast, UCN2-stimulated cyclic AMP accumulation was first significantly reduced by $10 \mathrm{nM} \mathrm{UCN} 3$ ( $\mathrm{p}<0.01$ ), with subsequent decreases produced by $100 \mathrm{nM} \mathrm{UCN} 3(\mathrm{p}<0.001)$ and $1 \mu \mathrm{M} \mathrm{UCN} 3$ $(\mathrm{p}<0.001)$ (Figure 2B). At each agonist concentration, however, UCN2 pretreatment produced significantly greater homologous $\mathrm{CRF}_{2(a)}$ receptor desensitization than UCN3 pretreatment $(\mathrm{p}<0.001)$ (Figure 2).

When Vale and colleagues cloned and sequenced UCN2 and UCN3 from mouse and human cDNA libraries [29,30], another group identified human UCN2- and UCN3-like peptides that were designated as "stresscopin" (SCP) and "stresscopin-related peptide" (SRP) [23]. In $\mathrm{Y} 79$ cells, the $\mathrm{EC}_{50}$ values for stimulation of cyclic AMP accumulation by the $\mathrm{CRF}_{2(a)}$ receptor are similar for human $\mathrm{UCN} 2$ and SRP, while the $\mathrm{EC}_{50}$ values for human UCN3and SCP-stimulated $\mathrm{CRF}_{2(a)}$ receptor cyclic AMP signaling are equivalent [17]. We found that cyclic AMP responsiveness to UCN2 in Y79 cells was desensitized to the same extent by a 15 -min exposure to either $100 \mathrm{nM} \mathrm{UCN} 2(88.6 \pm 0.8 \%$ decrease; $\mathrm{p}<0.001)$ or $100 \mathrm{nM}$ SRP $(91.5 \pm 0.9 \%$ decrease; $p<0.001)$. Further, UCN3-stimulated cyclic AMP accumulation was reduced to the same extent by pretreating Y79 cells with UCN3 $(70.4 \pm 1.5 \%$ decrease; $\mathrm{p}<0.001)$ or SCP $(66.3 \pm 1.8 \%)$ for $30 \mathrm{~min}$. Because the magnitude of homologous desensitization of $\mathrm{CRF}_{2(a)}$ receptors induced by UCN2 and SRP was equivalent, as was that produced by UCN3 and SCP, subsequent experiments compared the desensitizing effects of only UCN2 and UCN3.

To further confirm that the observed desensitization response resulted from the specific homologous actions of $\mathrm{UCN} 2$ and $\mathrm{UCN} 3$ on the $\mathrm{CRF}_{2(a)}$ receptor protein, we investigated the effect of the $\mathrm{CRF}_{2(\mathrm{a})}$ receptor-selective antagonist, antisauvagine-30 (ASV-30) in Y79 cells. ASV-30 pretreatment failed to desensitize UCN2-stimulated cyclic AMP accumulation compared to the large $\mathrm{CRF}_{2(\mathrm{a})}$ receptor desensitization $(77.9 \pm 2.3 \%$; $\mathrm{p}<0.001$ ) caused by UCN2 pretreatment (Figure $3 \mathrm{~A}$ ). Because $\mathrm{CRF}_{1}$ receptor cyclic AMP signaling has been reported to be activated by high concentrations of UCN2 [29], co-activation of $\mathrm{CRF}_{1}$ receptors could contribute to $\mathrm{CRF}_{2(\mathrm{a})}$ receptor desensitization. When Y79 cells were pretreated with a saturating concentration of the small molecule antagonist NBI-30775 that selectively blocks $\mathrm{CRF}_{1}$ receptor activation [5], the magnitudes of $\mathrm{CRF}_{2(\text { a) }}$ receptor desensitization produced by exposure to $100 \mathrm{nM} \mathrm{UCN} 2$ for $30 \mathrm{~min}$ were found to be similar in control Y79 cells $(82.9 \pm 1.3 \%)$ and NBI-30775-pretreated cells (79.7 $\pm 1.0 \%)$ (Figure 3B).

\subsection{Homologous $\mathrm{CRF}_{2}$ receptor desensitization induced by nonselective agonists urocortin 1, sauvagine, or corticotropin releasing factor}

Affinities and potencies of nonselective agonists for CRF receptors vary considerably. Urocortin 1 (UCN1) has an equivalent affinity and potency at both CRF receptors while human/rat $\mathrm{CRF}$ (h/rCRF) and ovine $\mathrm{CRF}$ (oCRF) bind to $\mathrm{CRF}_{2}$ receptors with $\sim 45$-fold and $\sim 185$-fold lower affinities, respectively [1-5,18]. Pretreatment with $\mathrm{h} / \mathrm{rCRF}$ for $30 \mathrm{~min}$ resulted in a markedly lower magnitude of $\mathrm{CRF}_{2(\mathrm{a})}$ receptor desensitization than that induced by the three urocortin peptides (Figure 4A,B). Furthermore, UCN2-stimulated cyclic AMP accumulation by retinoblastoma $\mathrm{CRF}_{2(\mathrm{a})}$ receptors failed to desensitize during a 30-min (Figure 4A) or 1-h exposure to oCRF (Control: $4.02 \pm 0.53$ pmoles $/ 10^{6}$ cells; $100 \mathrm{nM}$ oCRF pretreatment: $4.00 \pm 0.30$ pmoles $/ 10^{6}$ cells). Because UCN1 is the most non-selective $\mathrm{CRF}$ receptor agonist with equal potency at $\mathrm{CRF}_{1}$ and $\mathrm{CRF}_{2}$ receptors [1-5,18], we 
determined if any of the observed desensitization was attributable to UCN1 activation of $\mathrm{CRF}_{1}$ receptors. In these experiments, $\mathrm{Y} 79$ cells were incubated with a saturating concentration of UCN1 $(100 \mathrm{nM})$ for the longer agonist pretreatment period $(1 \mathrm{~h})$ required to desensitize $\mathrm{CRF}_{1}$ receptors [20,31], with and without the selective $\mathrm{CRF}_{1}$ receptor antagonist NBI-30775 $(1 \mu \mathrm{M})$ [5]. There was no statistically significant difference in the prominent homologous desensitization of UCN2-stimulated cyclic AMP accumulation resulting from UCN1 exposure in NBI-30775-pretreated cells $(79.3 \pm 1.4 \%$ decrease; $p<0.001)$ and cells exposed to UCN1 alone (Figure 4B). Similar to UCN1, the frog neuropeptide sauvagine also binds to both $\mathrm{CRF}_{1}$ and $\mathrm{CRF}_{2}$ receptors with equivalent subnanomolar affinities and equipotently activates Gs-coupled cyclic AMP signaling by both CRF receptors [1,2,18]. We have previously reported that sauvagine can desensitize retinoblastoma $\mathrm{CRF}_{1}$ receptors to a similar extent when Y79 cells are exposed to oCRF or UCN1 [31]. Equivalent degrees of homologous $\mathrm{CRF}_{2(\mathrm{a})}$ receptor desensitization were observed when Y79 cells were pretreated for 15 min or $1 \mathrm{~h}$ with $100 \mathrm{nM}$ sauvagine in the presence of the $\mathrm{CRF}_{1}$-selective antagonist NBI-30775 (38.0\% and 69.0\% desensitization, respectively) or without $\mathrm{CRF}_{1}$ receptor antagonism (39.8\% and $62.0 \%$ desensitization, respectively), commensurate with the affinity of sauvagine for the $\mathrm{CRF}_{2}$ receptor. Collectively, these data show not only that the nonselective $\mathrm{CRF}$ receptor ligands desensitize endogenous $\mathrm{CRF}_{2(a)}$ receptors independent of their activation of $\mathrm{CRF}_{1}$ receptors but also that the nonselective ligands with high affinity for $\mathrm{CRF}_{2(a)}$ receptors promote strong desensitization, a finding consistent with the results observed for the selective $\mathrm{CRF}_{2(\mathrm{a})}$ agonists.

\subsection{Effect of $\mathrm{CRF}_{2(\mathrm{a})}$ receptor desensitization on direct stimulation of cyclic AMP accumulation by forskolin and on Gs-coupled $\mathrm{PAC}_{1}$ and adrenergic receptor signaling in Y79 cells}

In contrast to UCN2 exposure inducing a $72 \%$ desensitization of $\mathrm{CRF}_{2(a)}$ receptors, the level of cyclic AMP responses stimulated by $50 \mu \mathrm{M}$ forskolin in Y79 cells pretreated with $100 \mathrm{nM}$ UCN2 for the same time period did not differ from forskolin-stimulated cyclic AMP accumulation in control cells (Figure 5A). This data indicates that the intrinsic activity of adenylyl cyclase was not altered by homologous desensitization of $\mathrm{CRF}_{2(\mathrm{a})}$ receptors induced by UCN2 exposure. Functional $\beta$-adrenergic receptors have been identified in Y79 cells [20]. Previously we demonstrated that Y79 cells also endogenously express pituitary adenylyl cyclase-activating polypeptide (PACAP) receptor type $1\left(\mathrm{PAC}_{1}\right)$, another regulator of the stress response, and that $\mathrm{PAC}_{1}$ receptors undergo rapid homologous desensitization via a GRK3 mechanism [32]. To test for heterologous regulation of $\mathrm{CRF}_{2(\mathrm{a})}$ receptors, UCN2-stimulated cyclic AMP accumulation was measured in Y79 cells in which a large degree of $\mathrm{PAC}_{1}$ receptor desensitization (56\%) was induced by PACAP38 pretreatment (10 $\mathrm{nM}$ for $1 \mathrm{~h}$ ) [32]. UCN2-stimulated cyclic AMP accumulation was not desensitized by PACAP38 pretreatment. Conversely, pretreatment of Y79 cells with $100 \mathrm{nM} \mathrm{UCN2}$ for 30 min failed to alter PACAP38- and isoproterenol-stimulated cyclic AMP accumulation while causing a prominent desensitization $(85 \%$; $\mathrm{p}<0.001)$ of $\mathrm{CRF}_{2(\mathrm{a})}$ receptors (Figure $5 \mathrm{~B}$ ). We conclude that $\mathrm{PAC}_{1}$ receptor signaling does not induce heterologous desensitization of the retinoblastoma $\mathrm{CRF}_{2(\mathrm{a})}$ receptor, and $\mathrm{CRF}_{2 \text { (a) }}$ receptor signaling does not result in heterologous desensitization of the $\mathrm{PAC}_{1}$ or $\beta$-adrenergic receptors.

\subsection{Lack of cross-desensitization of $\mathrm{CRF}_{1}$ and $\mathrm{CRF}_{2}$ receptors by selective agonists}

One receptor can regulate a related receptor subtype within the same GPCR subfamily. For example, $\mathrm{H} 1$ and $\mathrm{H} 2$ histamine receptors become cross-desensitized via a GRK2 mechanism and both histamine receptors undergo co-internalization upon agonist pretreatment of either $\mathrm{H} 1$ or $\mathrm{H} 2$ receptors [33]. Since $\mathrm{Y} 79$ cells express both $\mathrm{CRF}_{1}$ and $\mathrm{CRF}_{2(a)}$ receptors [17], we were able to determine if a cross-talk mechanism co-regulated both CRF receptors. We first employed $\mathrm{CRF}_{1}$-preferring agonists stressin-1A [34] and cortagine [35] to investigate 
whether or not $\mathrm{CRF}_{1}$ receptor activation regulated $\mathrm{CRF}_{2(\mathrm{a})}$ receptors in Y79 cells. While 1-h pretreatment of $\mathrm{Y} 79$ cells with $100 \mathrm{nM}$ stressin-1A or cortagine significantly desensitized CRF-stimulated cyclic AMP accumulation by $\mathrm{CRF}_{1}$ receptors, neither $\mathrm{CRF}_{1}$ receptorpreferring agonist desensitized UCN2-simulated cyclic AMP accumulation by $\mathrm{CRF}_{2 \text { (a) }}$ receptors (supplementary Table 2). As shown earlier, pretreating Y79 cells with the selective $\mathrm{CRF}_{1}$ receptor antagonist NBI-30775 to block UCN1-stimulated $\mathrm{CRF}_{1}$ receptor activation had no effect on homologous $\mathrm{CRF}_{2(\mathrm{a})}$ receptor desensitization induced by UCN1 (Figure 4B), an agonist that equipotently activates both CRF receptor subtypes with high affinity. To further confirm that $\mathrm{CRF}_{1}$ receptor signaling does not regulate $\mathrm{CRF}_{2(\mathrm{a})}$ receptors, $\mathrm{Y} 79$ cells were pretreated with $100 \mathrm{nM}$ oCRF for $1 \mathrm{~h}$ to maximally desensitize $\mathrm{CRF}_{1}$ receptors and then stimulated with $100 \mathrm{nM} \mathrm{UCN2}$. $\mathrm{CRF}_{2(\mathrm{a})}$ receptors were not desensitized to any extent in Y79 cells in which the 1-h oCRF exposure desensitized $\mathrm{CRF}_{1}$ receptors by decreasing

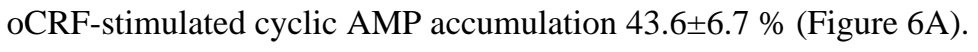

We next investigated whether UCN2- or UCN3-induced $\mathrm{CRF}_{2(a)}$ receptor activation heterologously desensitized retinoblastoma $\mathrm{CRF}_{1}$ receptors. The levels of $\mathrm{CRF}_{1}$ receptor cyclic AMP signaling in $\mathrm{Y} 79$ cells exhibiting strong $\mathrm{CRF}_{2(a)}$ receptor desensitization induced by $\mathrm{UCN} 2$ or $\mathrm{UCN} 3$, however, were similar to the level of $\mathrm{CRF}_{1}$ receptor cyclic AMP signaling in control cells without $\mathrm{UCN} 2$ or UCN3 pretreatment (Figure 6B).

Therefore, after having tested a large repertoire of both selective and non-selective CRF receptor agonists, we conclude that there is no significant cross-desensitization of $\mathrm{CRF}_{1}$ and $\mathrm{CRF}_{2(a)}$ receptors endogenously expressed in Y79 cells.

\subsection{Agonist-induced phosphorylation of $\mathrm{CRF}_{2(\mathrm{a})}$ receptors}

According to the classic model of homologous desensitization, agonist-activated receptors are phosphorylated by a family of G protein-coupled receptor kinases (GRKs) on specific serine/threonine residues in the receptor's third intracellular loop and/or carboxyl terminus $[13,14]$. Since there are no commercially available antibodies with the necessary high specificity and sensitivity to detect endogenous CRF receptors after phosphorylation and internalization, we used our well-characterized assays for measuring phosphorylation and subsequent trafficking of membrane CRF receptors with an HA epitope inserted at an inert region of the N-terminus and expressed in HEK293 cells [21,27]. Stimulation of HA$\mathrm{CRF}_{2(a)}$ receptor-expressing cells with $\mathrm{UCN} 2$ resulted in a time-dependent increase in a dense phospho- $\mathrm{CRF}_{2(\mathrm{a})}$ band with a $\mathrm{M}_{\mathrm{r}}$ of $60-70 \mathrm{kDa}$ in membrane fractions (Figure 7A), consistent with the known molecular size of the $\mathrm{CRF}_{2(\mathrm{a})}$ receptor protein [1-4]. $\mathrm{CRF}_{2(\mathrm{a})}$ receptor phosphorylation band density after 10-, 20-, and 40-min incubation with UCN2 was significantly increased 2.3- to 2.5-fold greater than the basal phosphorylation in control cells treated with media. The magnitudes of $\mathrm{CRF}_{2(a)}$ receptor phosphorylation stimulated by UCN2 and UCN3 (100 nM for $10 \mathrm{~min}$ ) were similar (Figure 7B). In contrast, a low level of $\mathrm{CRF}_{2(a)}$ receptor phosphorylation was measured in HEK293 cells incubated with $100 \mathrm{nM} \mathrm{h} /$ rCRF for $10 \mathrm{~min}$ (Figure 7B). Thus, CRF, an agonist deficient in its ability to induce $\mathrm{CRF}_{2(\mathrm{a})}$ receptor desensitization, also exhibited a very weak capacity to stimulate $\mathrm{CRF}_{2(\mathrm{a})}$ receptor phosphorylation.

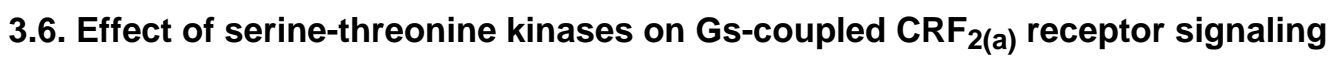

Protein kinase A (PKA) can homologously desensitize certain Gs-coupled GPCRs by phosphorylating serines and/or threonines within PKA consensus sites on the receptor's intracellular loops and/or C-terminus [13]. The $\mathrm{CRF}_{2(a)}$ receptor possesses a potential PKA phosphorylation site (RAS) at the beginning of the serine-threonine-rich sequence in the IC3 loop [1-3]. Thus, we determined if a PKA mechanism mediated homologous or heterologous $\mathrm{CRF}_{2(a)}$ receptor desensitization. Preincubating Y79 cells with the cellpermeable PKA inhibitor H89 prior to UCN2 pretreatment failed to alter homologous 
$\mathrm{CRF}_{2(\mathrm{a})}$ receptor desensitization (Figure 8A). Furthermore, the magnitude of UCN2stimulated cyclic AMP accumulation was similar in Y79 cells in which PKA was maximally activated by phosphodiesterase-resistant dibutyryl cyclic AMP or SpcAMP-S and in control cells without PKA activation (Figure 8B).

Casein kinases CK1 and CK2 can also desensitize GPCR signaling by phosphorylating intracellular serines and/threonines [36]. Since there are potential CK phosphorylation sites located within the IC3 loop (TTSE) and C-terminus (SIPT) of the $\mathrm{CRF}_{2(a)}$ receptor [1-3], we examined the effect of $\mathrm{CK} 1$ and $\mathrm{CK} 2$ inhibitors on the homologous $\mathrm{CRF}_{2(a)}$ receptor desensitization process in $\mathrm{Y} 79$ cells. UCN2-induced $\mathrm{CRF}_{2(a)}$ receptor desensitization was not inhibited in cells pretreated with the non-selective CK inhibitor TBB $(75.6 \pm 1.0 \%)$, the CK2-specific inhibitor quinalizarin (74.1 $\pm 1.0 \%)$, or the CK1-specific inhibitor IC261 (74.0 $\pm 2.4 \%)$, compared to control cells without CK inhibitor pretreatment $(74.4 \pm 1.1 \%)$ (Figure 8C).

In other experiments, we determined if PKA or casein kinase phosphorylated the HA-tagged $\mathrm{CRF}_{2(a)}$ receptor. $\mathrm{CRF}_{2(\mathrm{a})}$ receptor phosphorylation was not detected following maximal activation of PKA with dbcAMP (Figure 8D). In addition, pretreatment of HEK293 cells with PKA inhibitors $\mathrm{H} 89$ or RpcAMP did not reduce the 2 -fold increase in $\mathrm{CRF}_{2(\mathrm{a})}$ receptor phosphorylation stimulated by a saturating concentration of UCN2 (100 nM) (Figure 8D). Furthermore, UCN2 was still able to induce a 2-fold phosphorylation of the $\mathrm{CRF}_{2(\mathrm{a})}$ receptor in HEK293 cells in which CK1 and CK2 had been inhibited by TBB pretreatment (Figure $8 \mathrm{D})$. Hence, neither PKA nor casein kinase mechanisms are involved in the phosphorylation and desensitization of $\mathrm{CRF}_{2(\mathrm{a})}$ receptors.

\subsection{Agonist-induced $\mathrm{CRF}_{2(a)}$ receptor internalization}

We next used flow cytometry to study agonist-induced differences in internalization of $\mathrm{CRF}_{2(a)}$ receptors in transfected HEK293 cells that were used for the phosphorylation assay. In time course experiments (Figure $9 \mathrm{~A}), \mathrm{CRF}_{2(a)}$ receptors rapidly internalized in cells stimulated with $100 \mathrm{nM}$ UCN2 for $15 \mathrm{~min}(56.9 \pm 0.2 \%), 30 \mathrm{~min}(64.4 \pm 2.0 \%), 45 \mathrm{~min}$ $(65.8 \pm 0.2 \%)$, and $60 \mathrm{~min}(63.1 \pm 1.3 \%)$. Because we observed differential desensitization of $\mathrm{CRF}_{2(\mathrm{a})}$ receptors by urocortins and CRF in Y79 cells, we compared the magnitude of $\mathrm{CRF}_{2(a)}$ receptor internalization in transfected HEK293 cells stimulated with $100 \mathrm{nM}$ agonist for $30 \mathrm{~min} . \mathrm{CRF}_{2(a)}$ receptors internalized to a significantly $(\mathrm{p}<0.001)$ greater extent in response to $\mathrm{UCN} 2(64.4 \pm 2.0 \%)$ or $\mathrm{UCN} 3(53.7 \pm 3.7 \%)$ in comparison to the weak internalization resulting from $\mathrm{h} / \mathrm{rCRF}(27.9 \pm 3.5 \%)$ or oCRF $(14.9 \pm 0.1 \%)$ (Figure 9B). $\mathrm{CRF}_{2(\mathrm{a})}$ receptor internalization was significantly greater following UCN2 than UCN3 $(p<0.05)$ and following $r / h C R F$ than oCRF $(p<0.05)$. Finally, we determined the effect of the dynamin dominant negative mutant $\mathrm{K} 44 \mathrm{~A}$ on the $\mathrm{CRF}_{2(a)}$ receptor sequestration process. Internalization of $\mathrm{CRF}_{2(a)}$ receptors stimulated by a 30-min UCN2 exposure was inhibited $\sim 50 \%$ ( $\mathrm{p}<0.001$ ) in HEK293 cells co-transfected with K44A compared to cells cotransfected with an empty vector (Figure $9 \mathrm{C}$ ), suggesting that $\mathrm{CRF}_{2(\mathrm{a})}$ receptors internalize via a clathrin-mediated pathway.

\subsection{Characteristics of $\beta$ arrestin2 recruitment by $\mathrm{CRF}_{2(a)}$ receptors}

GRK-mediated phosphorylation of receptor proteins can increase the affinity of many GPCRs for $\beta$ arrestins up to 30-fold thereby promoting recruitment of $\beta$ arrestin proteins from the cytoplasm to the cell surface [13]. Binding of recruited $\beta$ arrestins to GRKphosphorylated GPCRs then sterically uncouples the receptor from its cognate G protein, resulting in the "arrest" or termination of agonist-mediated signal transduction [13-15]. $\beta$ Arrestins further contribute to the desensitization of many GPCRs by targeting them to clathrin-coated pits for endocytosis, resulting in the spatial uncoupling of the GPCR from 
the plasma membrane. To determine in real time and in living cells if activated $\mathrm{CRF}_{2(\mathrm{a})}$ receptors associate with $\beta$ arrestin proteins, and whether the pattern of $\beta$ arrestin recruitment varies in an agonist-specific manner, we employed a $\beta$ arrestin2-GFP fusion protein. HEK293 cells were co-transfected with $\mathrm{CRF}_{2(\mathrm{a})}$ receptor and $\beta$ arrestin2-GFP. The transfected cells were scanned using a confocal microscope prior to and after treatment with $\mathrm{UCN} 2, \mathrm{UCN} 3$, or h/rCRF. In the absence of agonist, ßarrestin2-GFP remained evenly distributed throughout the cytoplasm and was excluded from the nucleus (Figure 10). In cells exposed to $100 \mathrm{nM} \mathrm{UCN} 2$ or $100 \mathrm{nM} \mathrm{UCN} 3$ for $10 \mathrm{~min}$, ßarrestin 2 was strongly recruited from the cytoplasm to membrane $\mathrm{CRF}_{2(\mathrm{a})}$ receptors, depleting the observable cytoplasmic pool of $\beta$ arrestin2-GFP (Figure 10). In contrast, stimulation of $\mathrm{CRF}_{2(a)}$ receptor-expressing HEK293 cells with $100 \mathrm{nM} \mathrm{h/rCRF}$ for 10 min resulted in minimal

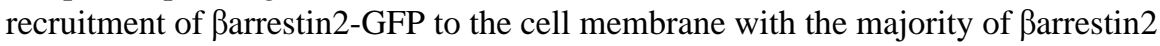
remaining in the cytoplasm (Figure 10). Treatment with $1 \mu \mathrm{M} \mathrm{h} / \mathrm{rCRF}$ for 10 min elicited a greater level of $\beta$ arrestin2 recruitment that was still, however, substantially weaker than that induced by $100 \mathrm{nM} \mathrm{UCN} 2$ and UCN3 (Figure 10). For all three ligands, a punctuate pattern of fluorescence was observed at the plasma membrane that likely reflects the localization of Barrestin2-GFP with $\mathrm{CRF}_{2(a)}$ receptors in clathrin coated pits (Figure 10). Longer agonist incubations of up to 1 hour did not alter the magnitude or pattern of $\beta$ arrestin2 recruitment to the cell surface.

The interaction of $\mathrm{CRF}_{2(a)}$ receptors with $\beta$ arrestin2 was further characterized by performing colocalization experiments in live HEK293 cells. Prior to agonist treatment, HA tagged$\mathrm{CRF}_{2(\mathrm{a})}$ receptors (red) localized to the plasma membrane and ßarrestin2-GFP (green) resided in the cytoplasm (Figure $11 \mathrm{~A}$ ). When these same HEK293 cells were stimulated with 100 nM UCN2 or UCN3, ßarrestin2 rapidly translocated within 2 minutes to the cell surface and prominently colocalized (yellow) with membrane $\mathrm{CRF}_{2(\mathrm{a})}$ receptors (Figure 11A). Following a 30-min treatment with $\mathrm{UCN} 2$ or $\mathrm{UCN} 3, \mathrm{CRF}_{2(\mathrm{a})}$ receptors were strongly internalized into endocytic vesicles (Figure 11B). ßarrestin2 proteins, however, did not traffic with these receptors inside the cell but continued to localize with $\mathrm{CRF}_{2(\mathrm{a})}$ receptors at the plasma membrane (Figure 11B). Taken together, these data suggest that the $\mathrm{CRF}_{2(\mathrm{a})}$ receptor, like the $\mathrm{CRF}_{1}$ receptor, is a "class A" GPCR in terms of its interaction with ßarrestin2, and this property is unaffected by binding UCN2 or UCN3 as the ligand. However, the magnitude of $\beta$ arrestin2 recruitment by the $\mathrm{CRF}_{2(a)}$ receptor depends dramatically upon the activating ligand with the more potent desensitizers UCN2 and UCN3 inducing a much stronger response.

At the saturating concentration of $100 \mathrm{nM}, \mathrm{UCN} 2$ and UCN3 appear visually to stimulate the same magnitude of $\beta$ arrestin2 recruitment to the $\mathrm{CRF}_{2(\mathrm{a})}$ receptor expressed in HEK293 cells (Figure 10). To determine if differences exist in the level of $\beta$ arrestin2 recruitment induced by these ligands and to investigate the concentration dependence of the response, we transiently expressed $\mathrm{CRF}_{2(a)}$ receptors in $\mathrm{U} 2 \mathrm{OS}$ cells and analyzed the redistribution of $\beta$ arrestin2-GFP using the INCell Analyzer 3000 [26]. U2OS cells were utilized for quantitation because of their superior adherent and morphological properties that allow for more sensitive measurements [25,37]. UCN2 and UCN3 concentration-response curves for Barrestin2-GFP translocation to $\mathrm{CRF}_{2(\text { a) }}$ receptors are depicted in Figure 12. Consistent with our findings in HEK293 cells, no significant differences were observed in the magnitude of Barrestin2 recruitment to the cell membrane in response to saturating concentrations of UCN2 (259 \pm 6 Fgrains) or UCN3 (266 \pm 10 Fgrains). However, an almost 10 -fold difference $(\mathrm{p}<0.0001)$ was observed for the $\mathrm{EC}_{50}$ values of $\beta$ arrestin2 recruitment by the $\mathrm{CRF}_{2(\mathrm{a})}$ receptor activated by $\mathrm{UCN} 2(1.76 \pm 0.06 \mathrm{nM})$ and $\mathrm{UCN} 3(15.13 \pm 0.08 \mathrm{nM})$, and these values correspond closely with the reported $\mathrm{K}_{\mathrm{d}}$ values for $\mathrm{CRF}_{2(\mathrm{a})}$ receptor binding of these two selective ligands $[17,18,29,30]$. 


\subsection{Barrestin2 regulation of Gs-coupled $\mathrm{CRF}_{2(\mathrm{a})}$ receptor signaling}

To investigate further $\beta$ arrestin2 control of $\mathrm{CRF}_{2(\mathrm{a})}$ receptor signal transduction, we assessed Gs-coupled $\mathrm{CRF}_{2(\mathrm{a})}$ receptor signaling in mouse embryonic fibroblast (MEF) cell lines derived from wild-type and ßarrestin knockout (KO) mice, which serve as an ideal cell system for studying $\beta$ arrestin-dependent mechanisms [22]. Cell surface expression of $\mathrm{CRF}_{2(a)}$ receptors was not significantly different in the $\beta$ arrestin2 KO MEF cells (44.5 \pm $3.4 \%)$ and wild-type MEF cells $(37.5 \pm 3.4 \%) 48 \mathrm{~h}$ following transfection. When UCN2 concentration-response curves for the stimulation of cyclic AMP accumulation were measured, we found that the maximum for UCN2-stimulated cyclic AMP accumulation was significantly increased more than 2-fold in $\beta$ arrestin2 KO MEF cells (15.82 \pm 0.40 pmoles/ well; $\mathrm{p}<0.001)$ compared to wild-type MEF cells with endogenous ßarrestin expression $(6.59 \pm 0.15 \mathrm{pmoles} /$ well) (Figure 13).

\section{Discussion}

The data reported herein establishes that the human $\mathrm{CRF}_{2(\mathrm{a})}$ receptor is stringently regulated by a rapid and strong desensitization mechanism following activation by the urocortins or related stresscopin peptides but not CRF. Furthermore, UCN2 and UCN3 at saturating concentrations stimulated similar high levels of $\mathrm{CRF}_{2(\mathrm{a})}$ receptor phosphorylation and maximal $\beta$ arrestin2 recruitment while $\mathrm{CRF}_{2(\mathrm{a})}$ receptors homologously desensitized and internalized via the dynamin/clathrin-mediated pathway to a greater degree in response to $\mathrm{UCN} 2$ compared to UCN3. In contrast, CRF induced very low levels of $\mathrm{CRF}_{2(a)}$ receptor phosphorylation, $\beta$ arrestin 2 recruitment, and internalization. These findings indicate the $\mathrm{CRF}_{2(a)}$ receptor adopts distinct conformations depending on the bound agonist that can modulate its $\beta$ arrestin2 recruitment, subcellular trafficking and functional regulation, perhaps through differences in picketing and fencing of the cell membrane by the actin cytoskeleton known to be involved in synaptic plasticity [38]. We also discovered that deletion of the $\beta$ arrestin2 gene in MEF cells significantly upregulated Gs-coupled $\mathrm{CRF}_{2(\mathrm{a})}$ receptor signaling activated by $\mathrm{UCN} 2$ and unrestrained by rapid homologous desensitization. Likewise, isoproterenol-stimulated cyclic AMP accumulation is abnormally high and prolonged in $\beta$ arrestin 2 knockout MEF cells expressing $\beta_{2}$-adrenergic adrenergic receptors [22], and $\mathrm{UCN} 2$-induced $\mathrm{CRF}_{2(\mathrm{~b})}$ receptor desensitization is greatly impaired when $\beta$ arrestin2 protein expression is knocked down by siRNA in HEK293 cells [16]. Neither protein kinase A nor casein kinase mechanisms, however, contributed to $\mathrm{CRF}_{2(a)}$ receptor phosphorylation and desensitization. Overall, our study suggests that the rate and magnitude of homologous desensitization of Gs-coupled signaling by the $\mathrm{CRF}_{2(a)}$ receptor is governed by the affinity and selectivity of agonist-induced conformations for triggering GRK-dependent phosphorylation, $\beta$ arrestin2 translocation, and dynamin/clathrin-dependent internalization.

Unlike the $\mathrm{CRF}_{1}$ receptor, the $\mathrm{CRF}_{2(\mathrm{a})}$ receptor binds and is activated by agonists with a broad range of potencies. Therefore, we assessed the ability of strong and weak ligands to desensitize retinoblastoma $\mathrm{CRF}_{2(a)}$ receptors. Although stresscopin's N-terminus is two amino acids longer than the $\mathrm{N}$-terminus of human $\mathrm{UCN} 3$, while the $\mathrm{N}$-terminus of stresscopin-related peptide is five amino acids longer than the N-terminus of human UCN2 [23], the robust levels of $\mathrm{CRF}_{2}$ (a) receptor desensitization were equivalent when comparing the effects of SCP to UCN3 and SRP to UCN2. Importantly, desensitization of cyclic AMP signaling by $\mathrm{CRF}_{2(\mathrm{a})}$ receptors generated by exposure to high-affinity, selective (UCN2, UCN3) or non-selective (UCN1, sauvagine) ligands was strikingly greater than that induced by the low-affinity, non-selective ligand CRF. Moreover, $\mathrm{CRF}_{2 \text { (a) }}$ receptors were only minimally phosphorylated and internalized weakly in response to high CRF concentrations known to saturate the receptor protein in contrast to the high magnitude and rapid rate of $\mathrm{CRF}_{2(\mathrm{a})}$ receptor phosphorylation and internalization elicited by the urocortins. Similarly, a 
recent report has shown that the $\mathrm{CRF}_{2(\mathrm{~b})}$ receptor, the peripheral $\mathrm{CRF}_{2}$ splice variant primarily expressed in cardiovascular, gastrointestinal, and muscle cells, homologously desensitized and internalized to a substantially greater extent in response to UCN2 compared to CRF in HEK293 cells [16]. Interestingly, activation of the $\beta_{2}$-adrenergic receptor by different agonists not only influenced the velocity and extent of GRK-mediated phosphorylation and desensitization but also resulted in different serine and threonine residues being phosphorylated in this receptor's C-terminus [39,40]. Furthermore, a recent fluorescence energy transfer (FRET) study concluded that weaker $\beta$ arrestin 2 recruitment and internalization of the $\beta_{2}$-adrenergic receptor activated by norepinephrine compared to stronger regulatory responses induced by epinephrine was a consequence of GRK5mediated phosphorylation being considerably less for norepinephrine compared to epinephrine potentially resulting in different receptor conformations [41]. Similarly, different serine-threonine phosphorylation "bar codes" on the $\mathrm{CRF}_{2(\mathrm{a})}$ receptor activated by urocortins or CRF may generate different conformations that govern the rate and magnitude of $\beta$ arrestin2 recruitment to cell surface $\mathrm{CRF}_{2(a)}$ receptors and their subsequent internalization.

Our study using real-time confocal microscopy in live cells provides the first evidence that the human $\mathrm{CRF}_{2(\mathrm{a})}$ receptor activated by $\mathrm{UCN} 2$ or $\mathrm{UCN} 3$ rapidly and strongly recruits GFPlabeled $\beta$ arrestin2 to the plasma membrane where $\beta$ arrestin2 proteins colocalize with $\mathrm{CRF}_{2(a)}$ receptor proteins. Similar to the $\mathrm{CRF}_{1}$ receptor [21,42], $\beta$ arrestin2 dissociates from the activated $\mathrm{CRF}_{2(\mathrm{a})}$ receptor at or near the plasma membrane and fails to internalize with the $\mathrm{CRF}_{2(\mathrm{a})}$ receptor as a unit into endocytic vesicles. Therefore, both CRF receptor isoforms exhibit a "class A" GPCR-arrestin interaction. A recent study using immunohistochemistry in fixed HEK293 cells found that the peripherally expressed $\mathrm{CRF}_{2(\mathrm{~b})}$ receptor also exhibits a "class A" interaction with $\beta$ arrestins [16]. To quantify differences in Barrestin2-GFP recruitment stimulated by the urocortins, we transiently expressed the $\mathrm{CRF}_{2(\mathrm{a})}$ receptors in U2OS cells, which allow for accurate and sensitive quantitation due to their superior adherent and morphological properties [21]. Although saturating concentrations of UCN2 and UCN3 stimulated similar high levels of $\mathrm{CRF}_{2(a)}$ receptor phosphorylation and maximal $\beta$ arrestin2 recruitment, we found the $\beta$ arrestin2 recruitment process to be more sensitive when $\mathrm{CRF}_{2(\mathrm{a})}$ receptors were activated by UCN2 compared to UCN3, in accordance with the more rapid desensitizing action of UCN2 compared to UCN3. Since UCN3 induces less $\mathrm{CRF}_{2(a)}$ receptor desensitization and internalization than that resulting from $\mathrm{UCN} 2$, the higher residual level of phosphorylated membrane $\mathrm{CRF}_{2(\mathrm{a})}$ receptors during UCN3 exposure may interact with recruited $\beta$ arrestin2 remaining near the membrane to promote UCN3-specific $\beta$ arrestin2-mediated signaling and other cellular events.

In contrast, exposure of $\mathrm{CRF}_{2(\mathrm{a})}$ receptors to $\mathrm{h} / \mathrm{rCRF}$ in living cells produced a strikingly weak translocation of $\beta$ arrestin2 to the membrane. Specifically, we found a markedly lower magnitude and slower rate of $\beta$ arrestin2 recruitment to $\mathrm{CRF}_{2(\mathrm{a})}$ receptors in response to $\mathrm{h} /$ rCRF concentrations as high as $1 \mu \mathrm{M}$ compared to the remarkably more rapid and greater ßarrestin2 translocation response induced by $100 \mathrm{nM} \mathrm{UCN} 2$ and UCN3. This observation agrees with our other findings that $\mathrm{h} / \mathrm{rCRF}$ induced weak phosphorylation, desensitization, and internalization of the $\mathrm{CRF}_{2(a)}$ receptor. A recent study reported, however, similar magnitudes of $\beta$ arrestin2 translocation to cell surface $\mathrm{CRF}_{2(\mathrm{~b})}$ receptors activated by $100 \mathrm{nM}$ $\mathrm{UCN} 2$ or h/rCRF [16]. The 406-414 amino acid $\mathrm{CRF}_{(2 \mathrm{a})}$ receptor and the 430-438 aminoacid $\mathrm{CRF}_{(2 \mathrm{~b})}$ receptor splice variants have identical sequences in their intracellular loops and C-terminal regions [1-6]. Substantial differences in their distal N-terminal extracellular domains may confer, however, distinct agonist-induced conformations to the two $\mathrm{CRF}_{2}$ receptor splice variants that result in differences in the extent and/or pattern of GRK phosphorylation and $\beta$ arrestin 2 recruitment in response to $\mathrm{UCN} 2$ or $\mathrm{h} / \mathrm{rCRF}$. Alternatively, 
activation of $\mathrm{CRF}_{2(\mathrm{a})}$ and $\mathrm{CRF}_{2(\mathrm{~b})}$ receptors by the same ligand may differentially expose phosphorylation-independent $\beta$ arrestin2 binding motifs. While GRK-mediated GPCR phosphorylation is critical for $\beta$ arrestin recruitment [13,14], recent studies have also shown that agonist-induced changes in receptor conformation independent of GRK phosphorylation can also play an important role in the interaction of ßarrestin2 with GPCRs including the $\mathrm{CRF}_{1}$ receptor $[21,43,44]$.

\section{Conclusion}

We have found unique profiles of $\mathrm{CRF}_{2(a)}$ receptor phosphorylation, $\beta$ arrestin2 recruitment, homologous desensitization, and dynamin/clathrin-mediated internalization conferred by binding of urocortins or CRF. Thus, differential desensitizing and internalizing actions of urocortins and CRF may generate agonist-specific regulation of $\mathrm{CRF}_{2(a)}$ receptors in brain neurons depending on which ligand is present. Increasing evidence indicates that "biased agonists" promote and stabilize distinct receptor conformations with functional selectivity for specific signal transduction pathways $[14,45]$. Previous studies using transfected CHO cells have demonstrated strong ERK signaling by recombinant $\mathrm{CRF}_{2(\mathrm{~b})}$ receptors activated by UCN2 but not CRF [46]. Our preliminary experiments have detected a large stimulation of Akt phosphorylation by $\mathrm{CRF}_{2(a)}$ receptors activated by $\mathrm{UCN} 2$ or $\mathrm{UCN} 3$ compared to minimal effects from binding CRF [Olivares-Reyes \& Hauger, unpublished data]. Rapid and strong recruitment of $\beta$ arrestin2 to the $\mathrm{CRF}_{2(\mathrm{a})}$ receptor during sustained exposure to UCN2 or UCN3 may shift signaling from G protein- to $\beta$ arrestin2-dependent pathways. $\mathrm{CRF}_{2 \text { (a) }}$ receptors are highly expressed in the hippocampus, the bed nucleus of the stria terminalis, and other regions of the and extended amygdala that have been implicated in posttraumatic stress disorder (PTSD) and mood pathophysiology [1,2,47]. Furthermore, prolonged severe stress and trauma upregulate expression of limbic $\mathrm{CRF}_{2(\mathrm{a})}$ receptors $[48,49]$. Stress also promotes $\mathrm{CRF}_{2(\mathrm{a})}$ receptor trafficking from the cytoplasm to the cell surface thereby rendering dorsal raphe neurons hyperexcitable (i.e., abnormally high discharge rates) due to excessive $\mathrm{CRF}_{2(\mathrm{a})}$ signaling [50]. Importantly, $\mathrm{G}$ protein-coupled hypersignaling by brain $\mathrm{CRF}_{2(\mathrm{a})}$ receptors has been found to promote startle hyperreactivity, persistent anxiety-like behavior, and contextual fear in mouse models of PTSD [10,11,48-51]. Thus, the failure to rapidly and strongly desensitize limbic $\mathrm{CRF}_{2(a)}$ receptors upregulated to abnormally high levels following stress and trauma due to deficient $\beta$ arrestin2 recruitment may be an important mechanism contributing to PTSD [52].

\section{Supplementary Material}

Refer to Web version on PubMed Central for supplementary material.

\section{Acknowledgments}

Dr. Hauger was supported by a BLR\&D Merit Review grant from the Department of Veterans Affairs, Veterans Health Administration, Office of Research and Development. Dr. Hauger also received support from the VA Center of Excellence for Stress and Mental Health (CESAMH), and NIH/NIA (AG018386) and NIH/NIMH (MH074697) RO1 grants. Dr. Oakley received support from the Intramural Research Program of the NIH, National Institute of Environmental Health Sciences, and completed a portion of the confocal microscopy experiments while he was employed at Xsira Pharmaceuticals (Morrisville, NC). Dr. Olivares-Reyes was supported by CINVESTAV-IPN, a UC MEXUS-CONACYT grant for collaborative projects, and a Grant for Research on Health from Fundacion Miguel Aleman 2010. Receptor internalization and cell surface receptor expression measurements were performed at the Flow Cytometry Research Core of the San Diego VA Research Service that is supported by DVA and a NIH/ NIAID RO1 (AI36214). We also grateful acknowledge Dr. Dimitri Grigoriadis and Neurocrine Biotechnology (La Jolla, CA) for generously providing NBI-30775 under an approved material transfer agreement. Dr. Robert Lefkowitz (HHMI, Duke University) kindly provided the ßarrestin KO and wild-type MEF cells under a material transfer agreement. 


\section{Keywords/Abbreviations}

CK1

CK2

CRF

$\mathrm{CRF}_{1}$ receptor

$\mathrm{CRF}_{\text {2(a) }}$ receptor

K44A

GPCR

GRK

PKA

PKC

UCN1

$\mathrm{UCN} 2$

UCN3

SCP

SRP casein kinase 1

casein kinase 2

corticotropin releasing factor receptor

CRF receptor type 1

CRF receptor type 2(a)

dynamin dominant negative mutant

$\mathrm{k} \mathrm{G}$ protein-coupled receptor

GPCR kinase; $\beta$ arrestin2

protein kinase $\mathrm{A}$

protein kinase $\mathrm{C}$

urocortin 1

urocortin 2

urocortin 3

stresscopin

stresscopin-related peptide

\section{References}

1. Hauger RL, Risbrough V, Brauns O, Dautzenberg FM. Corticotropin releasing factor (CRF) receptor signaling in the central nervous system: new molecular targets. CNS \& Neurological Disorders - Drug Targets. 2006; 5:453-479. [PubMed: 16918397]

2. Perrin, MH.; Vale, W. Chapter 25: Corticotropin-releasing factor receptors. In: Pangalos, MN.; Davies, CH., editors. Understanding G protein-coupled receptors and their role in the CNS. New York: Oxford University Press; 2002. p. 505-526.

3. Grammatopoulos DK. Insights into mechanisms of corticotropin-releasing hormone receptor signal transduction. Brit J Pharmacol. 2012; 166:85-97. [PubMed: 21883143]

4. Dautzenberg FM, Hauger RL. The CRF peptide family and their receptors: yet more partners discovered. Trends Pharmacol Sci. 2002; 23:71-77. [PubMed: 11830263]

5. Grigoriadis DE. The corticotropin-releasing factor receptor: a novel target for the treatment of depression and anxiety-related disorders. Expert Opin Ther Targets. 2005; 9:651-684. [PubMed: 16083336]

6. Hauger RL, Risbrough V, Oakley RH, Olivares-Reyes JA, Dautzenberg FM. Role of CRF receptor signaling in stress vulnerability, anxiety, and depression. Ann NY Acad Sci. 2009; 1179:120-143. [PubMed: 19906236]

7. Bale TL, Vale WW. CRF and CRF receptors: role in stress responsivity and other behaviors. Annu Rev Pharmacol Toxicol. 2004; 44:525-557. [PubMed: 14744257]

8. Keck ME, Ohl F, Holsboer F, Muller MB. Listening to mutant mice: a spotlight on the role of CRF/ CRF receptor systems in affective disorders. Neurosci Biobehav Rev. 2005; 29:867-889. [PubMed: 15899517]

9. Waselus M, Valentino RJ, Van Bockstaele E. Collaterized dorsal raphe nucleus projections: a mechanism for the integration of diverse functions during stress. J Chem Neuroanat. 2011; 41:266280. [PubMed: 21658442]

10. Lebow M, Neufeld-Cohen A, Kuperman Y, Tsoory M, Gil S, Chen A. Susceptibility to PTSD-like behavior is mediated by corticotropin-releasing factor receptor type 2 levels in the bed nucleus of the stria terminalis. J Neurosci. 2012; 32:6906-6916. [PubMed: 22593059] 
11. Risbrough VB, Hauger RL, Roberts AL, Vale WW, Geyer MA. Corticotropin releasing factor receptors CRF1 and CRF2 exert both additive and opposing influences on defensive startle behavior. J Neurosci. 2004; 24:6545-6552. [PubMed: 15269266]

12. Risbrough VB, Geyer MA, Hauger RL, Coste S, Stenzel-Poore M, Wurst W, Holsboer F. CRF1 and CRF2 receptors are required for potentiated startle to contextual but not discrete cues. Neuropsychopharmacology. 2009; 34:1494-1503. [PubMed: 19020499]

13. Kohout TA, Lefkowitz RJ. Regulation of G protein-coupled receptor kinases and arrestins during receptor desensitization. Mol Pharmacol. 2003; 63:9-18. [PubMed: 12488531]

14. Shenoy SK, Lefkowitz RJ. $\beta$-arrestin-mediated receptor trafficking and signal transduction. Trends Pharmacol Sci. 2011; 32:521-533. [PubMed: 21680031]

15. Oakley RH, Laporte SA, Holt JA, Caron MG, Barak LS. Differential affinities of visual arrestin, $\beta$ arrestin1, and $\beta$-arrestin2 with $G$ protein-coupled receptors delineate two major classes of receptors. J Biol Chem. 2000; 275:17201-17210. [PubMed: 10748214]

16. Markovic D, Punn A, Lehnert H, Grammatopoulos DK. Intracellular mechanisms regulating corticotropin-releasing hormone receptor-2b endocytosis and interaction with extracellularly regulated kinase 1/2 and p38 mitogen-activated protein kinase signaling cascades. Mol Endocrinol. 2008; 22:689-706. [PubMed: 18048641]

17. Gutknecht E, Hauger RL, Van der Linden I, Georges Vauquelin G, Dautzenberg FM. Expression, binding, and signaling properties of $\mathrm{CRF}_{2}$ (a) receptors endogenously expressed in human retinoblastoma Y79 cells: passage-dependent regulation of functional receptors. J Neurochem. 2008; 104:926-936. [PubMed: 17976162]

18. Dautzenberg FM, Gutknecht E, Van der Linden I, Olivares-Reyes JA, Dürrenberger F, Hauger RL. Cell type specific calcium signaling by corticotropin-releasing factor type $1\left(\mathrm{CRF}_{1}\right)$ and $2 \mathrm{a}$ $\left(\mathrm{CRF}_{2(\mathrm{a})}\right)$ receptors: $\mathrm{G}_{\mathrm{q}}$ coupling in human embryonic kidney 293 but not SK-N-MC neuroblastoma cells. Biochem Pharmacol. 2004; 68:1833-1844. [PubMed: 15450949]

19. Palchaudhuri MR, Hauger RL, Wille S, Fuchs E, Dautzenberg FM. Isolation and pharmacological characterization of two functional splice variants of corticotropin releasing factor type 2 receptor from Tupaia belangeri. J Neuroendocrinol. 1999; 11:419-428. [PubMed: 10336722]

20. Dautzenberg FM, Braun S, Hauger RL. GRK3 mediates desensitization of $\mathrm{CRF}_{1}$ receptors: a potential mechanism regulating stress adaptation. Am J Physiol. 2001; 280:R935-R946.

21. Oakley RH, Olivares-Reyes JA, Hudson CC, Flores-Vega F, Dautzenberg FM, Hauger RL. Carboxyl terminal and intracellular loop sites for $\mathrm{CRF}_{1}$ receptor phosphorylation and $\beta$ arrestin2 recruitment: a mechanism regulating stress and anxiety responses. Am J Physiol. 2007; 293:R209_ R222.

22. Kohout TA, Lin F-T, Perry SJ, Conner DA, Lefkowitz RJ. $\beta$-Arrestin 1 and 2 differentially regulate heptahelical receptor signaling and trafficking. Proc Natl Acad Sci USA. 2001; 98:16011606. [PubMed: 11171997]

23. Hsu SY, Hsueh AJ. Human stresscopin and stresscopin-related peptide are selective ligands for the type 2 corticotropin-releasing hormone receptor. Nat Med. 2001; 7:605-611. [PubMed: 11329063]

24. Oakley RH, Laporte SA, Holt JA, Barak LS, Caron MG. Molecular determinants underlying the formation of stable intracellular $\mathrm{G}$ protein-coupled- $\beta$-arrestin complexes after receptor endocytosis. J Biol Chem. 2001; 276:19452-19460. [PubMed: 11279203]

25. Oakley, RH.; Cowan, CL.; Hudson, CC.; Loomis, CR. Transfluor provides a universal cell-based assay for screening $\mathrm{G}$ protein coupled receptors. In: Minor, L., editor. Handbook of Assay Development in Drug Discovery. New York: Marcel Dekker; 2006. p. 435-457.

26. Oakley RH, Hudson CC, Cruickshank RD, Meyers DM, Payne RE, Rehm SM, Loomis CR. The cellular distribution of fluorescently labeled arrestins provides a robust, sensitive, and universal assay for screening G protein-coupled receptors. Assay Drug Develop Tech. 2002; 1:21-30.

27. Hauger RL, Smith RD, Braun S, Dautzenberg FM, Catt KJ. Rapid agonist-induced phosphorylation of the human CRF receptor, type 1: a potential mechanism for homologous desensitization. Biochem Biophys Res Comm. 2000; 268:572-576. [PubMed: 10679245]

28. Clark RB, Knoll BJ, Barber R. Partial agonists and G protein-coupled receptor desensitization. Trends Pharmacol Sci. 1999; 20:279-286. [PubMed: 10390646] 
29. Lewis K, Li C, Perrin MH, Blount A, Kunitake K, Donaldson C, Vaughan J, Reyes TM, Gulyas J, Fischer W, Bilezikjian L, Rivier J, Sawchenko PE, Vale WW. Identification of urocortin III, an additional member of the corticotropin-releasing factor (CRF) family with high affinity for the CRF2 receptor. Proc Natl Acad Sci (USA). 2001; 98:7570-7575. [PubMed: 11416224]

30. Reyes TM, Lewis K, Perrin MH, Kunitake KS, Vaughan J, Arias CA, Hogenesch JB, Gulyas J, Rivier J, Vale WW, Sawchenko PE. Urocortin II: a member of the corticotropin-releasing factor (CRF) neuropeptide family that is selectively bound by type 2 CRF receptors. Proc Natl Acad Sci USA. 2001; 98:2843-2848. [PubMed: 11226328]

31. Dautzenberg FM, Wille S, Braun S, Hauger RL. GRK3 regulation during CRF- and urocortininduced $\mathrm{CRF}_{1}$ receptor desensitization. Biochem Biophys Res Commun. 2002b; 298:303-308. [PubMed: 12413940]

32. Dautzenberg FM, Hauger RL. G protein receptor kinase 3- and protein kinase C-mediated desensitization of the PACAP receptor, type 1 in human Y-79 retinoblastoma cells. Neuropharmacology. 2001; 40:394-407. [PubMed: 11166332]

33. Alonso N, Fernandez N, Notcovich C, Monczor F, Simaan M, Baldi A, Gutkind S, Davio C, Shayo C. Cross-desensitization and cointernalization of $\mathrm{H} 1$ and $\mathrm{H} 2$ histamine receptors reveal new insights into histamine signal integration. Mol Pharmacol. 2013; 83:1087-1098. [PubMed: 23462507]

34. Rivier J, Gulyas J, Kunitake K, DiGruccio M, Cantle JP, Perrin MH, Donaldson C, Vaughan J, Million M, Gourceroi G, Adelson DW, Rivier C, Tache Y, Vale W. Stressin-1A, a potent corticotrophin releasing factor receptor 1 (CRF1)-selective peptide agonist. J Med Chem. 2007; 50:1668-1674. [PubMed: 17335188]

35. Tezval H, Jahn O, Todorovic C, Sasse A, Eckart K, Spiess J. Cortagine, a specific agonist of corticotropin-releasing factor receptor subtype 1, is anxiogenic and antidepressive in the mouse model. Proc Natl Acad Sci USA. 2004; 101:9468-9473. [PubMed: 15192151]

36. Tobin A. Are we beta-ARKing up the wrong tree? Casein kinase 1 alpha provides an additional pathway for GPCR phosphorylation. Trends Pharmcol Sci. 2002:337-343.

37. Oakley, RH.; Barak, LS.; Caron, MG. Real time imaging of GPCR-mediated arrestin translocation as a strategy to evaluate receptor-protein interactions. In: George, SR.; O’Dowd, BF., editors. G Protein Coupled Receptor-Protein Interactions. Hoboken, NJ: John Wiley \& Sons; 2005. p. 53-80.

38. Milan-Lobo L, Gsandtner I, Gaubitzer E, Runzler D, Buchmayer F, Kohler G, Bonci A, Freissmuth M, Sitte HH. Subtype-specific differences in corticotropin-releasing factor receptor complexes detected by fluorescence spectroscopy. Mol Pharmacol. 2009; 76:1196-1210. [PubMed: 19755522]

39. Krasel C, Vilardaga JP, Bunemann M, Lohse MJ. Kinetics of G-protein-coupled receptor signaling and desensitization. Biochem Soc Trans. 2004; 32:1029-1031. [PubMed: 15506955]

40. Trester-Zedlitz M, Burlingame A, Kobilka B, von Zastrow M. Mass spectrometric analysis of agonist effects on posttranslational modifications of the $\beta_{2}$-adrenergic receptor. Biochemistry. 2005; 44:6133-6143. [46] Trester-Zedlitz M, Burlingame A, Kobilka B, von Zastrow M. Mass spectrometric analysis of agonist effects on posttranslational modifications of the $\beta_{2}$-adrenergic receptor. Biochemistry 2005;44:6133-6143. [PubMed: 15835901]

41. Reiner S, Ambrosio M, Hoffmann C, Lohse MJ. Differential signaling of the endogenous agonist at the beta2-adrenergic receptor. J Biol Chem. 2010; 285:36188-36198. [PubMed: 20837485]

42. Holmes KD, Babwah AV, Dale LB, Poulter MO, Ferguson SS. Differential regulation of corticotropin releasing factor 1alpha receptor endocytosis and trafficking by beta-arrestins and Rab GTPases. J Neurochem. 2006; 96:934-949. [PubMed: 16412099]

43. Marion S, Oakley RH, Kim KM, Caron MG, Barak LS. A beta-arrestin binding determinant common to the second-intracellular loops of Rhodopsin-family $\mathrm{G}$ protein-coupled receptors. J Biol Chem. 2006; 281:2932-2938. [PubMed: 16319069]

44. Kelly E, Bailey CP, Henderson G. Agonist-selective mechanisms of GPCR desensitization. Brit Pharmacol. 2008; 153(Suppl 1):S379-S388.

45. Whalen EJ, Rajagopal S, Lefkowitz RJ. Therapeutic potential of $\beta$-arrestin- and G protein-biased agonists. Trends Mol Med. 2011 in press. 
46. Brar BK, Chen A, Perrin MH, Vale W. Specificity and regulation of extracellularly regulated kinase-1/2 phosphorylation through corticotropin-releasing factor (CRF) receptors 1 and $2 b$ by the CRF/urocortin family of peptides. Endocrinology. 2004; 145:1718-1729. [PubMed: 14670995]

47. Van Pett K, Viau V, Bittencourt JC, Chan RKW, Li H-Y, Arias C, Prins GS, Perrin M, Vale W, Sawchenko PE. Distribution of mRNAs encoding CRF receptors in brain and pituitary of rat and mouse. J Comp Neurol. 2000; 428:191-212. [PubMed: 11064361]

48. Sananbenesi F, Fischer A, Schrick C, Spiess J, Radulovic J. Mitogen-activated protein kinase signaling in the hippocampus and its modulation by corticotropin-releasing factor receptor 2: a possible link between stress and fear memory. J Neurosci. 2003; 23:11436-11443. [PubMed: 14673008]

49. Ventura-Silva AP, Pego JM, Sousa JC, Marques AR, Rodrigues AJ, Marques F, Cerqueira JJ, Almeida OFX, Sousa N. Stress shifts the response of the bed nucleus of the stria terminalis to an anxiogenic mode. Eur J Neurosci. 2012 in press.

50. Waselus M, Nazzaro C, Valentino RJ, Van Bockstaele EJ. Stress-induced redistribution of corticotropin-releasing factor receptor subtypes in the dorsal raphe nucleus. Biol Psychiatry. 2009; 66:76-83. [PubMed: 19362706]

51. Neufeld-Cohen A, Kelly PAT, Paul ED, Carter RN, Skinner E, Olverman HJ, Vaughan JM, Issler O, Kuperman Y, Lowry CA, Vale WW, Seckl JR, Chen A, Jamieson PM. Chronic activation of corticotropin-releasing factor receptor type 2 receptors reveals a key role of 5-HT1A receptor responsiveness in mediating behavioral and serotonergic responses to stressful challenge. Biol Psychiatry. 2012; 72:437-447. [PubMed: 22704666]

52. Hauger RL, Olivares-Reyes JA, Braun S, Dautzenberg FM, Oakley RH. Molecular and cell signaling targets for PTSD pathophysiology and pharmacotherapy. Neuropharmacology. 2012; 62:705-714. [PubMed: 22122881] 


\section{Highlights}

- $\mathrm{CRF}_{2(a)}$ receptors are rapidly and strongly desensitized by urocortins but not CRF.

- Urocortins but not CRF strongly internalize $\mathrm{CRF}_{2(\mathrm{a})}$ into dynamin/clathrin pits.

- Urocortins but not CRF induce rapid, strong class $\mathrm{A} \mathrm{CRF}_{2(\mathrm{a})}-\beta$ arrestin2 interactions.

- Gs-coupled $\mathrm{CRF}_{2(\mathrm{a})}$ signaling is upregulated in cells with a $\beta$ arrestin2 gene deletion.

- Agonist-specific receptor conformations govern Gs-coupled $\mathrm{CRF}_{2}$ signaling regulation. 


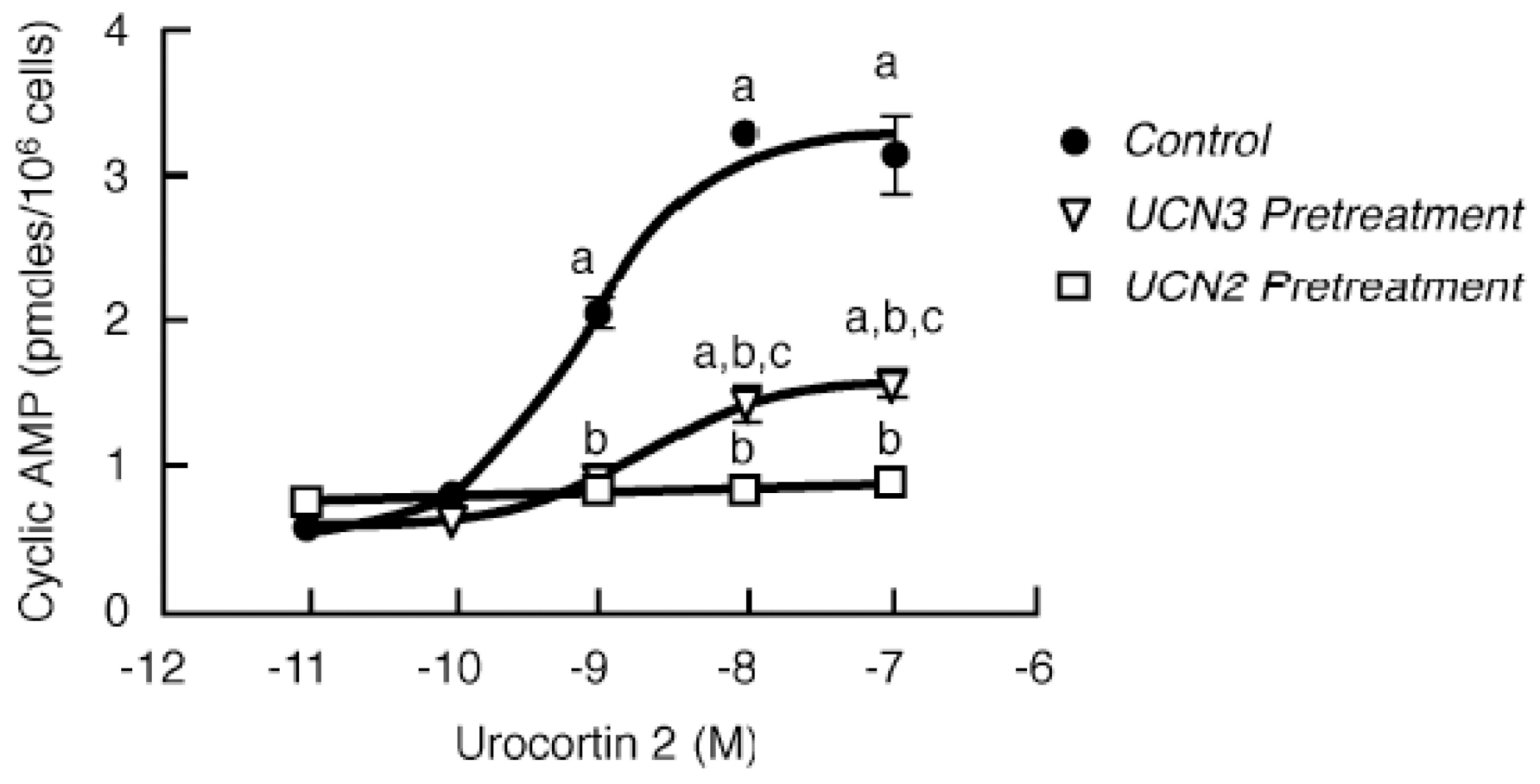

Figure 1. Effect of homologous $\mathrm{CRF}_{2}$ (a) receptor desensitization on sensitivity $\left(\mathrm{EC}_{50}\right)$ and maximum for the concentration-response stimulation of intracellular cyclic AMP accumulation by urocortin 2

Homologous $\mathrm{CRF}_{2(a)}$ receptor desensitization was induced by pretreating Y79 cells with UCN2 (100 nM) or UCN3 (100 nM) for $30 \mathrm{~min}$. Cyclic AMP levels (pmoles/10 6 cells) were then measured in triplicate in desensitized and control cells stimulated with $0-100 \mathrm{nM}$ UCN2 for $15 \mathrm{~min}$. By ANOVA, there was a significant interaction $[\mathrm{F}=68.0 ; \mathrm{p}<0.0001]$ for group (Control or Urocortin Pretreatment) and stimulation conditions $\left(10^{-11}\right.$ to $10^{-7} \mathrm{M}$ $\mathrm{UCN} 2$ ). A significant within group effect $[\mathrm{F}=114.5$; $\mathrm{p}<0.0001]$ was found with planned comparisons indicating the following: ${ }^{\mathrm{a}} \mathrm{p}<0.001 \mathrm{vs}$ Basal (no UCN2). A significant across pretreatment group effect $[\mathrm{F}=208.8 ; \mathrm{p}<0.0001]$ was detected with planned comparisons indicating the following differences: ${ }^{b} \mathrm{p}<0.001 \mathrm{vs}$ Control (no pretreatment); ${ }^{\mathrm{c}} \mathrm{p}<0.05 \mathrm{vs}$ UCN2 pretreatment. These findings were confirmed in four independent experiments. 
A.

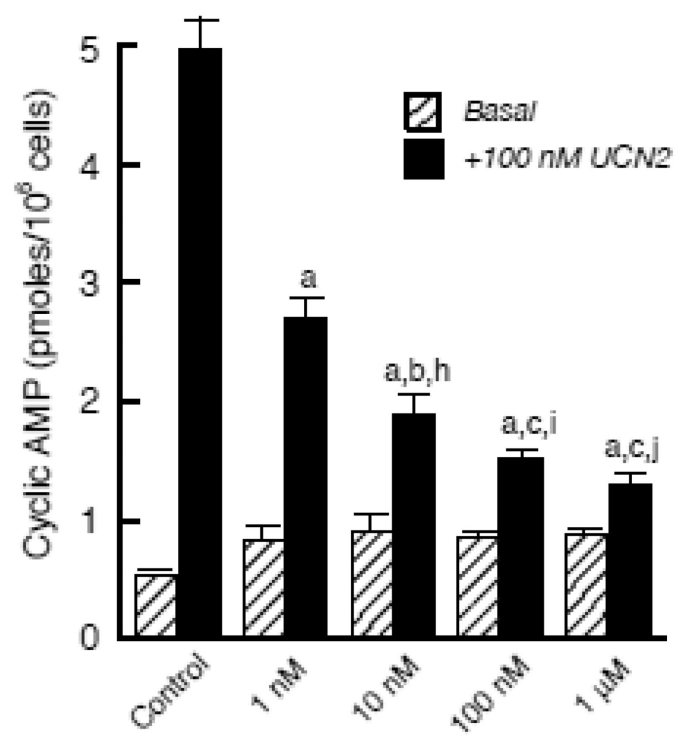

UCN 2 Pretreatment (15 min)

B.

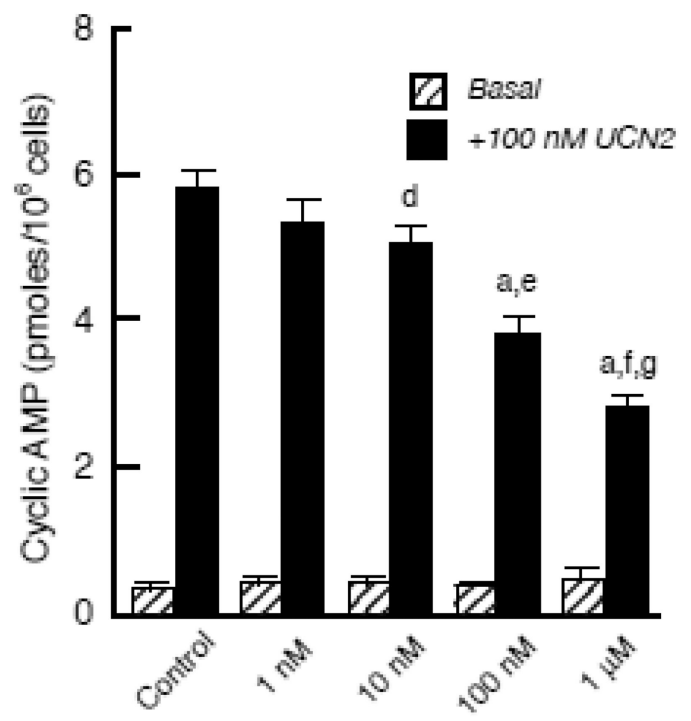

UCN 3 Pretreatment (15 min)

Figure 2. Concentration-dependence of homologous $\mathrm{CRF}_{2}$ receptor desensitization induced by urocortin 2 or 3

After Y79 cells were pretreated with UCN2 (A), UCN3 (B), or buffer (Control), cyclic AMP levels (pmoles $/ 10^{6}$ cells) were measured in washed cells following an additional incubation with buffer (Basal) or maximal stimulation with $100 \mathrm{nM} \mathrm{UCN} 2$ for $15 \mathrm{~min}$. Results were obtained in five independent experiments $(n=10$ replicates per pretreatment group). By ANOVA, there was a significant interaction $[\mathrm{F}=77.41 ; \mathrm{p}<0.0001]$ for pretreatment group (Urocortin concentration) and stimulation condition (Basal - no UCN2 or +100 nM UCN2). There were also significant within group differences for UCN2 Pretreatment $[\mathrm{F}=514.1$; $\mathrm{p}<0.0001]$ and UCN3 Pretreatment [F=1492; $<<0.0001]$. Planned comparisons detected 
significant differences in UCN2-stimulated cyclic AMP stimulation within UCN2 Pretreatment groups $\left({ }^{\mathrm{a}} \mathrm{p}<0.001\right.$ vs Control; ${ }^{b} \mathrm{p}<0.01$ vs $1 \mathrm{nM} \mathrm{UCN} 2 ;{ }^{c} \mathrm{p}<0.001$ vs $1 \mathrm{nM}$ UCN2) and within UCN3 Pretreatment groups ( ${ }^{a} \mathrm{p}<0.001$ vs Control; ${ }^{\mathrm{d}} \mathrm{p}<0.01$ vs Control; ${ }^{\mathrm{e}} \mathrm{p}<0.01$ vs $10 \mathrm{nM} \mathrm{UCN} 3$; $\mathrm{f}_{\mathrm{p}}<0.001$ vs $10 \mathrm{nM} \mathrm{UCN} 3$; ${ }_{\mathrm{p}}<0.05$ vs $100 \mathrm{nM} \mathrm{UCN} 3$ ). When the calculated $\Delta$ cyclic AMP responses (+100 nM UCN2 stimulation - Basal cyclic AMP levels) for the UCN2 and UCN3 Pretreatment groups were compared, the ANOVA detected significant across group (UCN2 vs UCN3 Pretreatment) interactions [F=90.42; $\mathrm{p}<0.0001]$, with planned comparisons indicating significantly greater desensitization by UCN2 than UCN3 at the following concentrations: ${ }^{{ }^{h}}<<0.001$ vs $100 \mathrm{nM} \mathrm{UCN} 3 ;{ }^{i} \mathrm{p}<0.01$ vs 1 $\mu \mathrm{M} \mathrm{UCN} 3 ; ;{ }_{\mathrm{p}}<0.01$ vs $1 \mu \mathrm{M} \mathrm{UCN} 3$. 


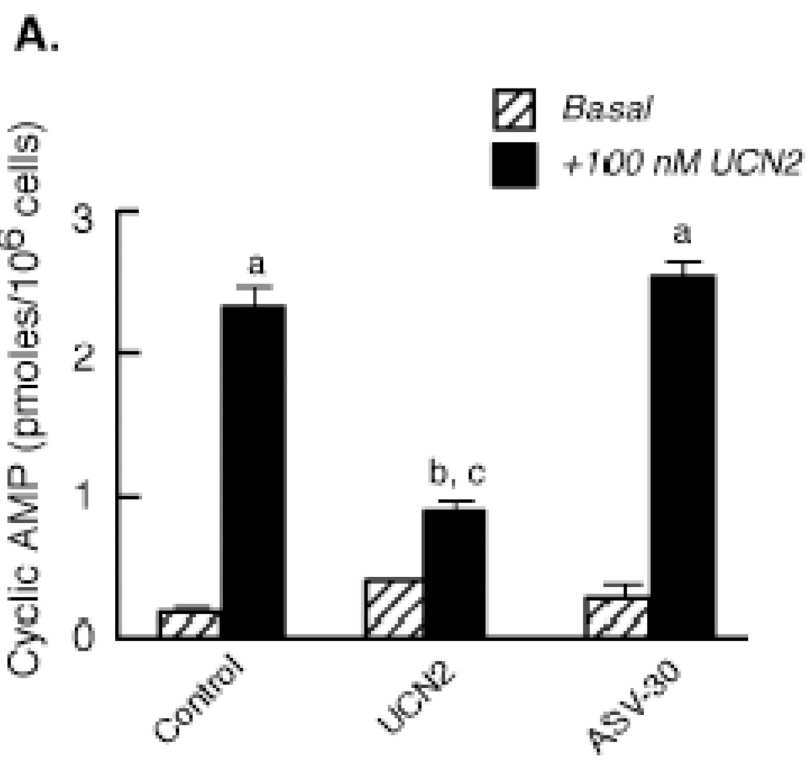

Pretreatment
B.

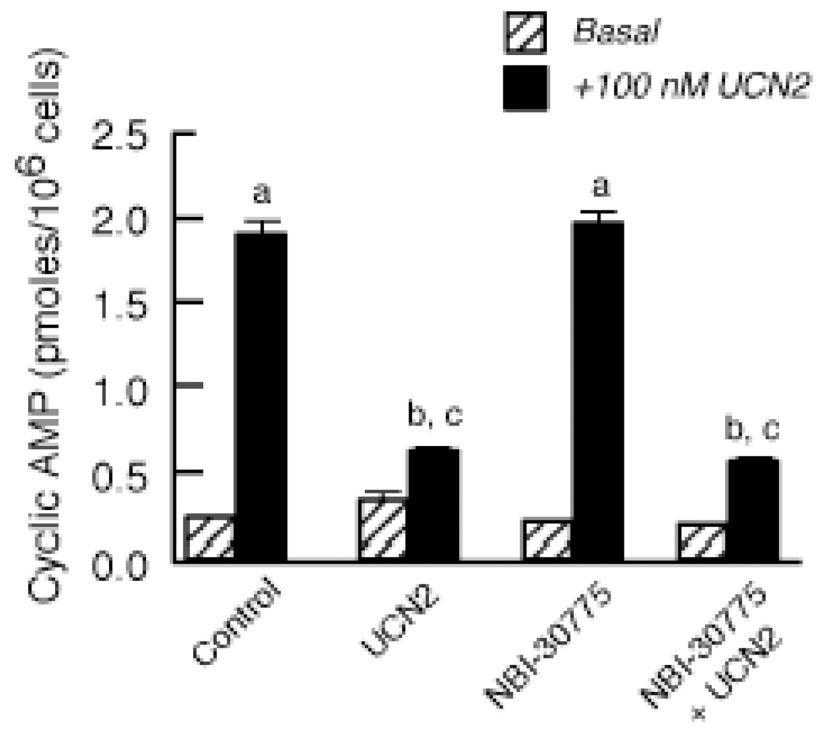

Pretreatment

Figure 3. Effect of $\mathrm{CRF}_{1}$ and $\mathrm{CRF}_{2}$ receptor antagonists on $\mathrm{UCN2}$-stimulated cyclic $\mathrm{AMP}$ accumulation

(A) The effects of 15-min pretreatment with the selective $\mathrm{CRF}_{2}$ receptor antagonist antisauvagine-30 (ASV-30 $100 \mathrm{nM}$ ), UCN2 (100 nM), or buffer (Control) on UCN2stimulated cyclic AMP accumulation were compared. Data (mean \pm SEM) are cyclic AMP levels (pmoles $/ 10^{6}$ cells; $n=9$ ) measured in cells incubated with buffer (Basal) or maximally stimulated with $100 \mathrm{nM}$ UCN2 for $15 \mathrm{~min}(+100 \mathrm{nM} \mathrm{UCN} 2)$ after the pretreatment period. By ANOVA, there was a significant interaction $[\mathrm{F}=94.43 ; \mathrm{p}<0.0001]$ for pretreatment group (Control, UCN2, ASV-30) and stimulation conditions (Basal - no $\mathrm{UCN} 2$ or $+100 \mathrm{nM} \mathrm{UCN} 2$ ). A significant within group effect $[\mathrm{F}=750.7 ; \mathrm{p}<0.0001]$ was observed with planned comparisons indicating the following: ${ }^{\mathrm{a}} \mathrm{p}<0.001$ vs Basal. There was also a significant effect $[\mathrm{F}=63.88 ; \mathrm{p}<0.0001]$ across the pretreatment groups with planned comparisons indicating the following differences in $+100 \mathrm{nM} \mathrm{UCN} 2$ stimulation: ${ }^{\mathrm{b}} \mathrm{p}<0.001$ vs Control; ${ }^{\mathrm{c}} \mathrm{p}<0.001$ vs ASV-30. These results were replicated in two independent experiments. (B) After Y79 cells were pretreated with $100 \mathrm{nM} \mathrm{UCN2}$ or buffer (Control) for $30 \mathrm{~min}$ in the presence or absence of the selective $\mathrm{CRF}_{1}$ receptor antagonist NBI-30775, cyclic AMP levels (pmoles $/ 10^{6}$ cells; $n=9$ ) were measured in washed cells incubated with buffer (Basal) or maximally stimulated with $100 \mathrm{nM} \mathrm{UCN} 2$ for $15 \mathrm{~min}$ (+100 nM UCN2). By ANOVA, there was a significant interaction $[\mathrm{F}=265.4 ; \mathrm{p}<0.0001]$ for pretreatment group (Control, UCN2, NBI-30775, NBI-30775 + UCN2) and stimulation condition (Basal or $+100 \mathrm{nM}$ UCN2). A significant within group effect was observed with planned comparisons indicating the following: ${ }^{\mathrm{a}} \mathrm{p}<0.001 \mathrm{vs}$ Basal. There was also a significant effect $[\mathrm{F}=239.2$; $\mathrm{p}<0.0001]$ across the pretreatment groups with planned comparisons indicating the following differences in $+100 \mathrm{nM}$ UCN2 stimulation: ${ }^{b} \mathrm{p}<0.001$ vs Control; ${ }^{\mathrm{c}} \mathrm{p}<0.001$ vs NBI-30775. These results were replicated in two independent experiments. 


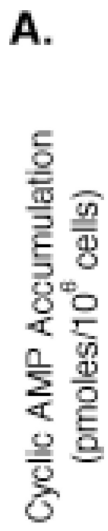

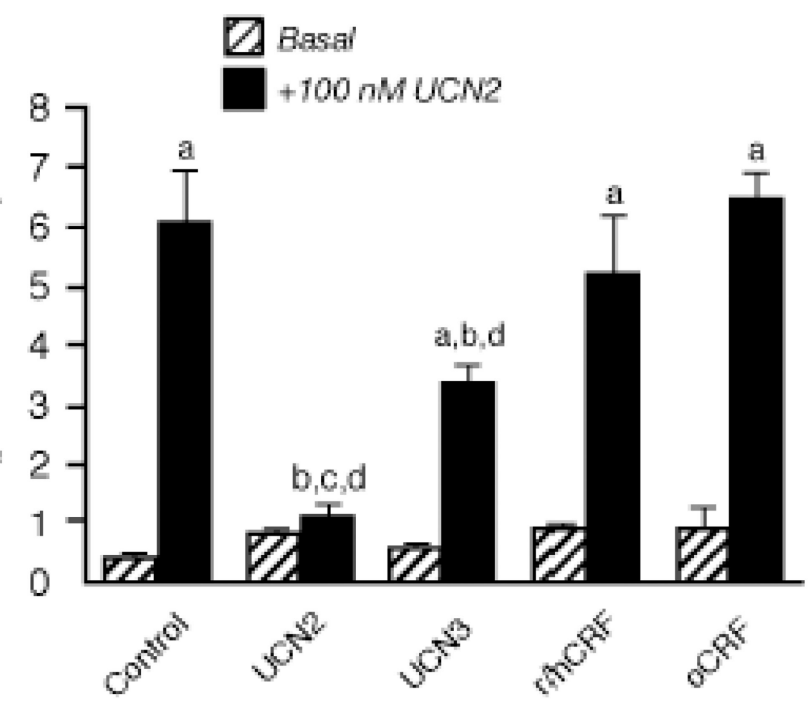

Agonist Pretreatment

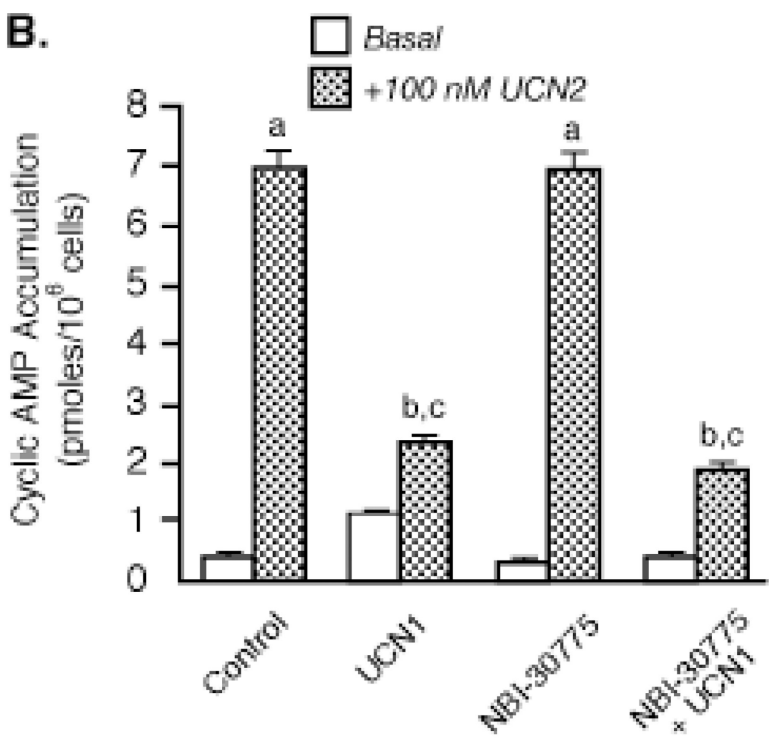

Pretreatment Conditions

Figure 4. Comparison of the magnitude of homologous $\mathrm{CRF}_{2}$ receptor desensitization induced by urocortins and CRF

(A) After Y79 cells were pretreated with 100 nM UCN2, UCN3, r/hCRF, or oCRF for 30 min, cyclic AMP levels (pmoles $/ 10^{6}$ cells; $n=6$ ) were measured in washed cells incubated with buffer (Basal) or maximally stimulated for $15 \mathrm{~min}$ (+100 nM UCN2). By ANOVA, there was a significant interaction $[\mathrm{F}=64.04 ; \mathrm{p}<0.0001]$ for pretreatment group (Control, $\mathrm{UCN} 2, \mathrm{UCN} 3, \mathrm{CRF}$ ) and stimulation condition (Basal or $+100 \mathrm{nM} \mathrm{UCN} 2$ ). A significant within group effect was found with planned comparisons indicating the following: ${ }^{\mathrm{a}} \mathrm{p}<0.001$ vs Basal. There was also a significant effect $[\mathrm{F}=239.2 ; \mathrm{p}<0.0001]$ across pretreatment groups with planned comparisons indicating the following differences for $+100 \mathrm{nM} \mathrm{UCN} 2$ stimulation: ${ }^{b} \mathrm{p}<0.001$ vs Control; ${ }^{c} \mathrm{p}<0.001 \mathrm{vs}$ r/hCRF; ${ }^{\mathrm{d}} \mathrm{p}<0.001$ vs oCRF. These results were replicated in five independent experiments. (B) After Y79 cells were pretreated for $1 \mathrm{~h}$ with buffer (Control) or $100 \mathrm{nM}$ urocortin 1 (UCN1) in the presence or absence of the selective $\mathrm{CRF}_{1}$ receptor antagonist NBI-30775, they were then incubated with buffer (Basal) or maximally stimulated with $100 \mathrm{nM}$ UCN2 for 15 min and cyclic AMP levels (pmoles/10 6 cells, $n=9$ ) measured. By ANOVA, there was a significant interaction $[\mathrm{F}=197.1 ; \mathrm{p}<0.0001]$ for pretreatment group (Control, UCN1, NBI-30775, NBI-30775 + UCN1) and stimulation condition (Basal or $+100 \mathrm{nM} \mathrm{UCN2}$ ). A significant within group effect was found with planned comparisons indicating the following: ${ }^{\mathrm{a}} \mathrm{p}<0.001 \mathrm{vs}$ Basal. There was also a significant effect $[\mathrm{F}=138.9 ; \mathrm{p}<0.0001]$ across the pretreatment groups with planned comparisons indicating the following differences for $+100 \mathrm{nM}$ UCN2 stimulation: ${ }^{\mathrm{b}} \mathrm{p}<0.001$ vs Control; ${ }^{c} \mathrm{p}<0.001$ vs NBI-30775. These results were replicated in three independent experiments. 


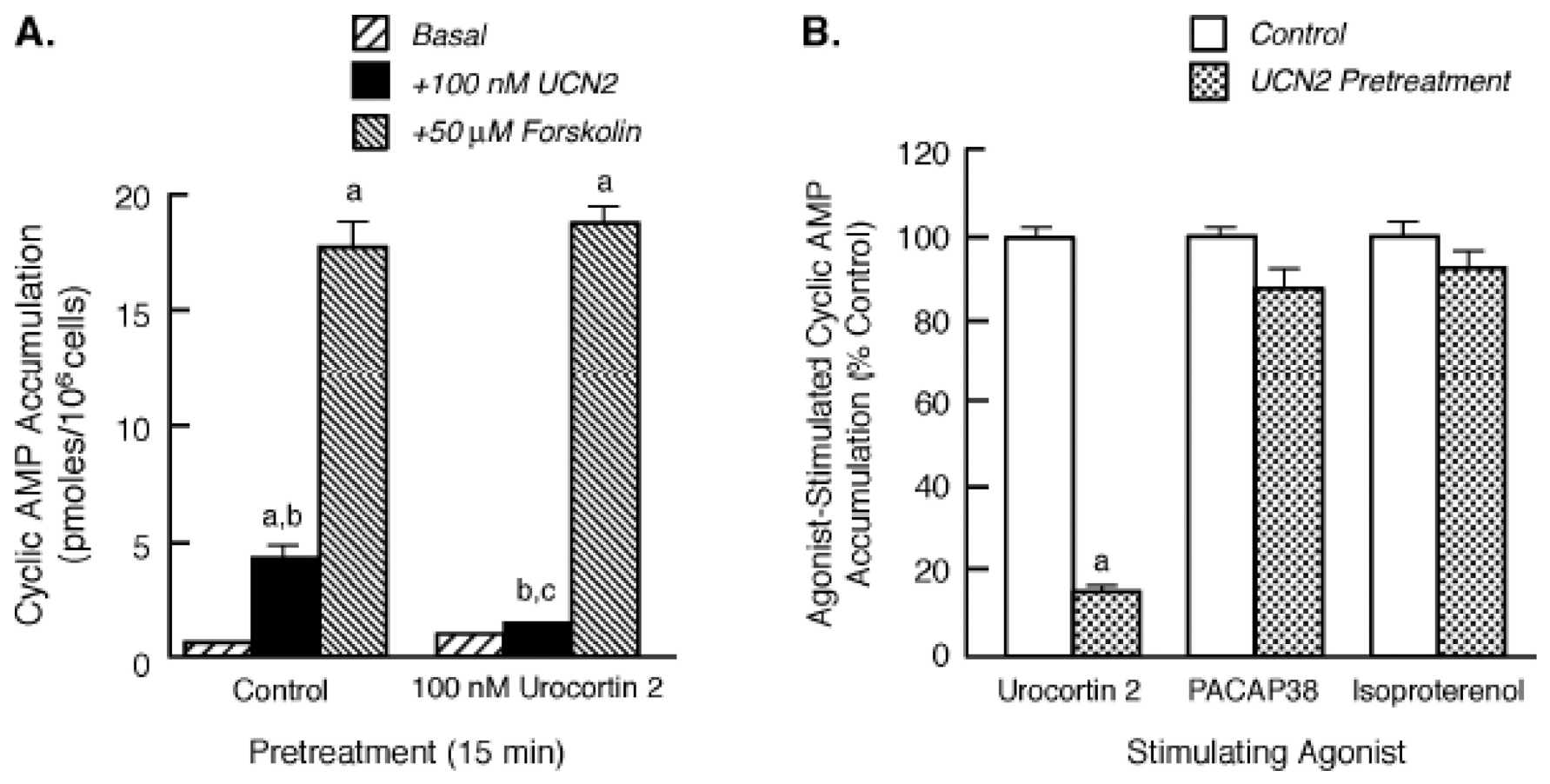

Figure 5. Effect of homologous $\mathrm{CRF}_{2}$ receptor desensitization on the ability of forskolin, PACAP38, and isoproterenol to stimulate intracellular cyclic AMP accumulation

(A) After homologous $\mathrm{CRF}_{2}$ receptor desensitization was induced by exposing $\mathrm{Y} 79$ cells to UCN2, cyclic AMP levels (pmoles $/ 10^{6}$ cells) were then measured in desensitized and control (no UCN2 pretreatment) cells incubated for 15 min with buffer (Basal), UCN2, or forskolin ( $\mathrm{n}=10$ /condition). By ANOVA, there was a significant interaction $[\mathrm{F}=5.88$; $\mathrm{p}<0.005$ ] for pretreatment group (Control, UCN2) and stimulation condition (Basal, $+\mathrm{UCN} 2$, or + Forskolin). A significant within group effect $[\mathrm{F}=709.7 ; \mathrm{p}<0.0001]$ was found with planned comparisons indicating the following differences: ${ }^{a} \mathrm{p}<0.001 \mathrm{vs}$ Basal; ${ }^{\mathrm{b}} \mathrm{p}<0.001$ vs Forskolin. A significant effect $[\mathrm{F}=3.59 ; \mathrm{p}<0.05]$ was detected across the two pretreatment groups with planned comparisons indicating the following difference for $+100 \mathrm{nM}$ UCN2 stimulation: ${ }^{\mathrm{c}} \mathrm{p}<0.001$ vs Control. These findings were replicated in two independent experiments. (B) After Y79 cells were pretreated with buffer (Control) or 100 nM UCN2 for $30 \mathrm{~min}$, cyclic AMP responses (\%Control) to a 15-min stimulation with $100 \mathrm{nM}$ UCN2, 100 $\mathrm{nM}$ PACAP38, or $10 \mu \mathrm{M}$ isoproterenol ( $\mathrm{n}=12$ /group) were then measured in control and desensitized. By ANOVA, there were significant differences across the Control and UCN2 Pretreatment groups $[\mathrm{F}=108.2, \mathrm{p}<0.0001]$ with planned comparisons indicating the following: ${ }^{a} \mathrm{p}<0.001 \mathrm{vs}$ Control. These findings were replicated in two independent experiments. 


\author{
CRF-R2a $\square$ Basal \\ CRF-R2a $\square+100$ nM UCN2 \\ CRF-R1 $\searrow$ Basal \\ CRF-R1 $\square+100$ nM OCRF
}

\author{
CRF-R2a $\square$ Basal \\ CRF-R2a $\square+100$ nM UCN2 \\ CRF-R1 \ Basal \\ CRF-R1 $\square+100 \mathrm{nM}$ oCRF
}

\section{A. CRF $_{1}$ Receptor Desensitization}

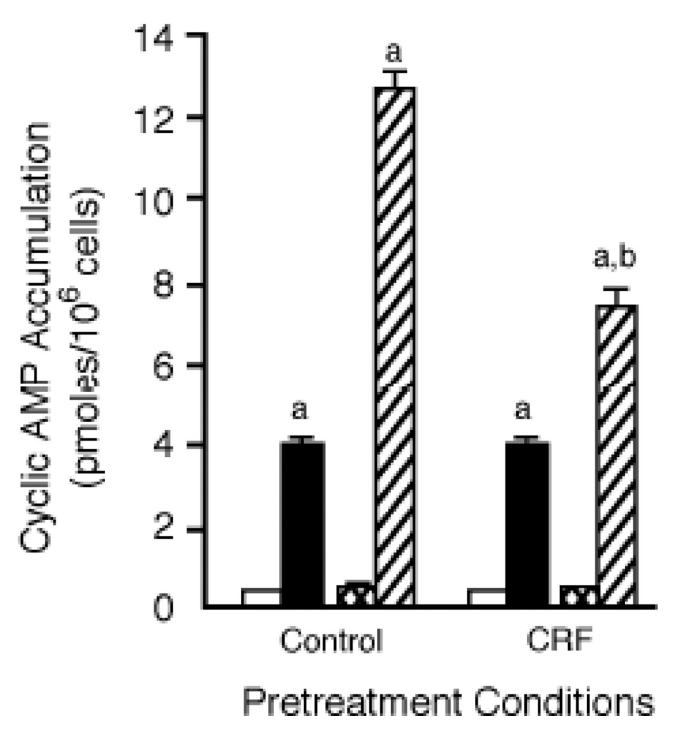

\section{B. CRF $_{2}$ Receptor Desensitization}

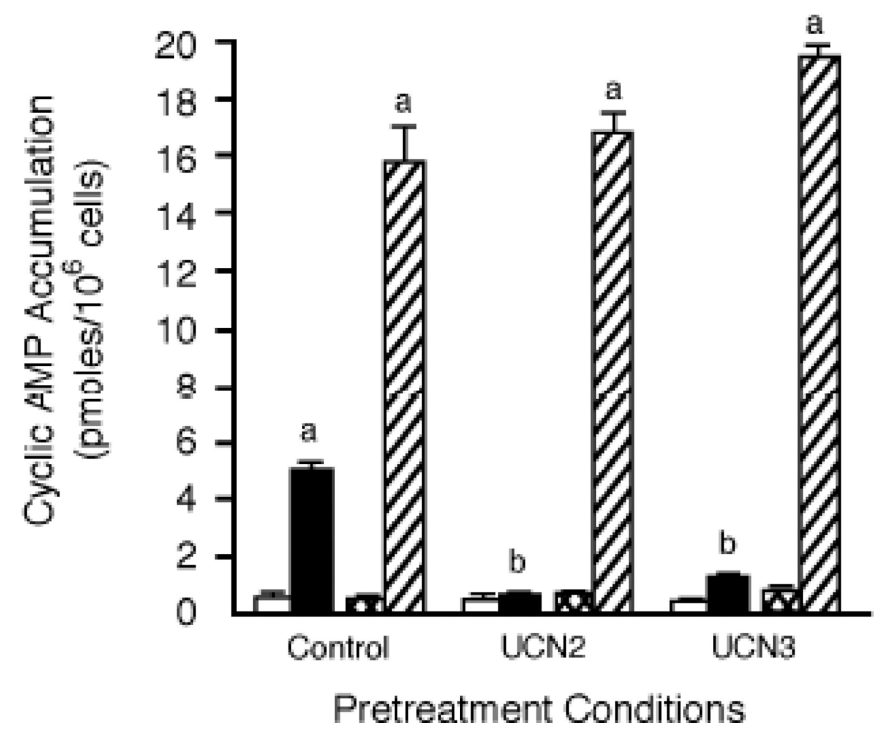

Figure 6. Independence of homologous desensitization processes controlling signal transduction by $\mathrm{CRF}_{1}$ and $\mathrm{CRF}_{2}$ receptors co-expressed in $\mathrm{Y79}$ cells

(A) The effect of prolonged CRF exposure on Gs-coupled $\mathrm{CRF}_{2}$ receptor signaling was determined by pretreating Y79 cells with buffer (Control) or $100 \mathrm{nM}$ oCRF for $1 \mathrm{~h}$ (to induce maximal $\mathrm{CRF}_{1}$ receptor desensitization [20]). Cyclic AMP accumulation (pmoles/ $10^{6}$ cells; $\mathrm{n}=9$ ) was then measured after $\mathrm{CRF}_{2(\mathrm{a})}$ receptors $(\mathrm{CRF}-\mathrm{R} 2 \mathrm{a})$ were maximally stimulated by $\mathrm{UCN} 2(+100 \mathrm{nM} \mathrm{UCN} 2)$ or $\mathrm{CRF}_{1}$ receptors (CRF-R1) were maximally stimulated by CRF (+100 $\mathrm{nM}$ oCRF) for $15 \mathrm{~min}$. By ANOVA, there was a significant interaction $[\mathrm{F}=27.92 ; \mathrm{p}<0.0001]$ for pretreatment conditions (Control, $\mathrm{CRF}$ ) and stimulation group (Basal, $+100 \mathrm{nM}$ UCN2 or $+100 \mathrm{nM}$ oCRF). A significant within group effect was found with planned comparisons indicating the following: ${ }^{\mathrm{a}} \mathrm{p}<0.001$ vs Basal. There was also a significant effect across the pretreatment groups with planned comparisons indicating the following differences for $+100 \mathrm{nM}$ CRF stimulation: ${ }^{b} \mathrm{p}<0.001$ vs Control. These results were replicated in three independent experiments. (B) The effect of prolonged urocortin exposure on Gs-coupled $\mathrm{CRF}_{1}$ receptor signaling was assessed in $\mathrm{Y} 79$ cells by incubation with buffer (Control), or pretreatment with $100 \mathrm{nM} \mathrm{UCN} 2$ or UCN3 for $1 \mathrm{~h}$ (to induce maximal $\mathrm{CRF}_{2}$ receptor desensitization). Cyclic AMP accumulation (pmoles $/ 10^{6}$ cells; $\mathrm{n}=$ 13) was then measured after $\mathrm{CRF}_{1}$ receptors (CRF-R1) were maximally stimulated by CRF (+100 nM oCRF) or $\mathrm{CRF}_{2(a)}$ receptors (CRF-R2a) were maximally stimulated by UCN2 (+100 nM UCN2) for $15 \mathrm{~min}$. By ANOVA, there was a significant interaction $[\mathrm{F}=11.20$; $\mathrm{p}<0.0001]$ for pretreatment conditions (Control, UCN2, UCN3) and stimulation group (Basal, +100 nM UCN2 or +100 nM oCRF). A significant within group effect was found with planned comparisons indicating the following: ${ }^{\mathrm{a}} \mathrm{p}<0.001$ vs Basal. There was also a significant effect across the pretreatment groups with planned comparisons indicating the following differences for $+100 \mathrm{nM} \mathrm{UCN} 2$ stimulation: ${ }^{b} \mathrm{p}<0.001$ vs Control. These results were replicated in three independent experiments. These results were replicated in four independent experiments. 
A.

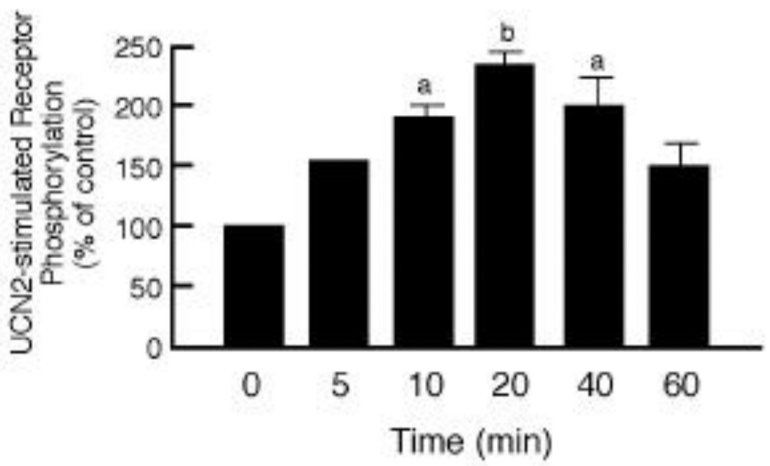

B.
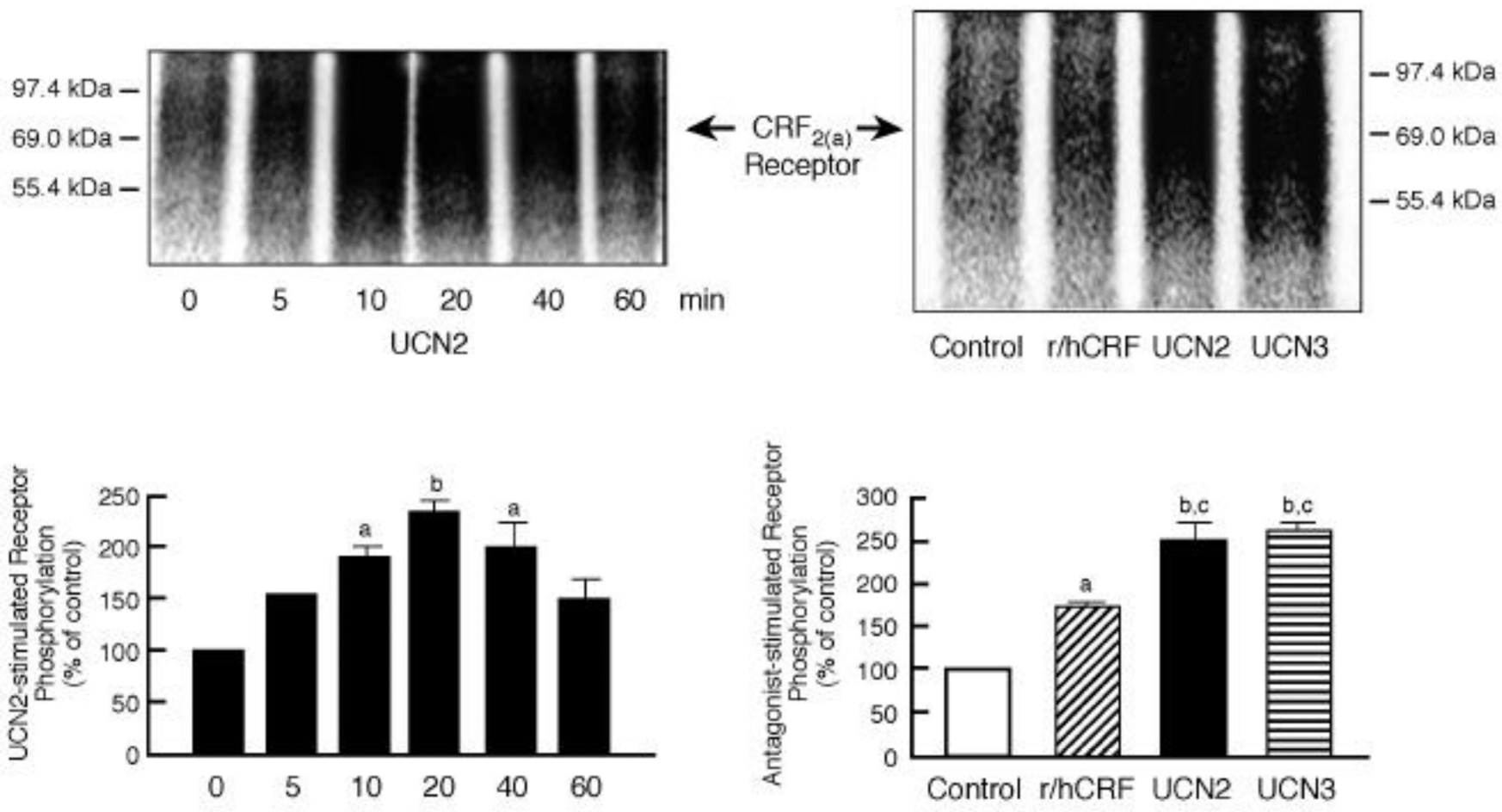

Figure 7. Agonist-stimulated phosphorylation of membrane $\mathrm{CRF}_{2(a)}$ receptors

(A) $72 \mathrm{~h}$ after transfection with $\mathrm{HA}$-tagged $\mathrm{CRF}_{2(\mathrm{a})}$ receptor cDNA, HEK293 cells were metabolically labeled with ${ }^{32} \mathrm{P}_{\mathrm{i}}$ and then stimulated with $100 \mathrm{nM}$ UCN2 for 0-60 min. By ANOVA with planned comparisons, the levels of phosphorylated $\mathrm{CRF}_{2(\mathrm{a})}$ receptor $\left(\mathrm{M}_{\mathrm{r}} 60\right.$ $70 \mathrm{kDa}$ ) measured by densitometry were significantly increased: ${ }^{\mathrm{a}} \mathrm{p}<0.05$ vs 0 min UCN2 (Control); ${ }^{\mathrm{b}} \mathrm{p}<0.01$ vs $0 \mathrm{~min}$ (Control). This data was replicated in three independent experiments. (B) The magnitude of $\mathrm{CRF}_{2(a)}$ receptor phosphorylation was compared following a 10 min stimulation with buffer (Control) or $100 \mathrm{nM}$ agonist (r/hCRF, UCN2, UCN3). ANOVA with planned comparisons detected the following significant differences in $\mathrm{CRF}_{2(\mathrm{a})}$ phosphorylation bands: ${ }^{\mathrm{a}} \mathrm{p}<0.01$ vs Control; ${ }^{\mathrm{b}} \mathrm{p}<0.001$ vs Control; ${ }^{\mathrm{c}} \mathrm{p}<0.01 \mathrm{vs} \mathrm{r} /$ hCRF. This data was replicated in three independent experiments. 

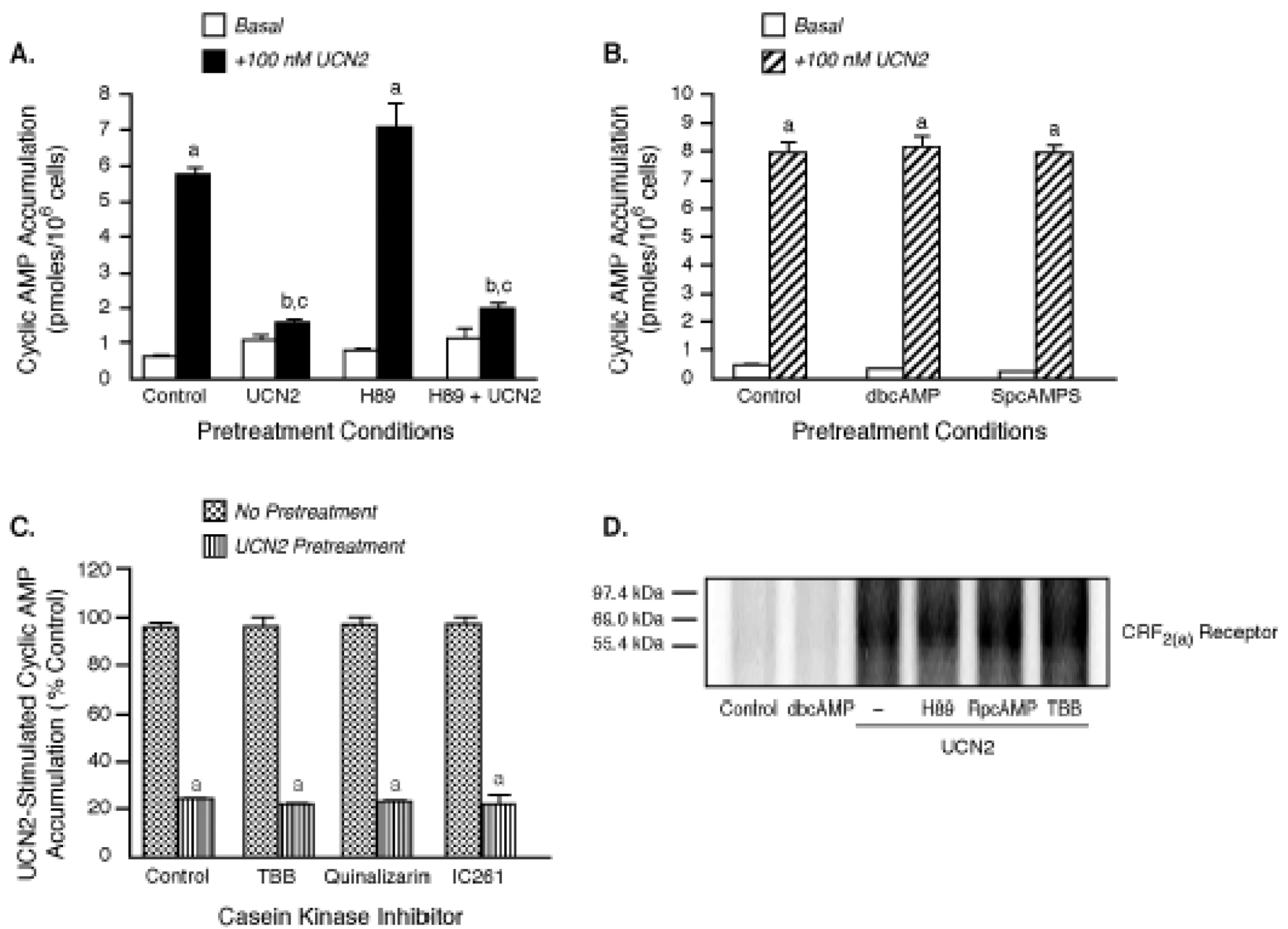

Figure 8. The role of protein kinase $A$ and casein kinases in the regulation of Gs-coupled $\mathrm{CRF}_{2(\text { a) }}$ receptor signaling

(A) Effect of protein kinase A (PKA) inhibition on homologous $\mathrm{CRF}_{2 \text { (a) }}$ receptor desensitization. In the pretreatment period, Y79 cells were first incubated with media or H89 $(2 \mu \mathrm{M})$ for $30 \mathrm{~min}$ and then exposed to media (Control) or UCN2 $(100 \mathrm{nM})$ in the continuing presence of $\mathrm{H} 89$ for an additional $15 \mathrm{~min}$. Pretreated cells were then incubated with buffer (Basal, $n=3)$ or stimulated with UCN2 (+100 nM UCN2, n=10) for an additional 15 min. By ANOVA, there was a significant interaction $[\mathrm{F}=17.09 ; \mathrm{p}<0.0001]$ for pretreatment group (Control, UCN2, H89, H89 + UCN2) and stimulation condition (Basal or +100 nM UCN2). A significant within group effect $[\mathrm{F}=77.27$; $\mathrm{p}<0.0001]$ was found with planned comparisons indicating the following: ${ }^{a} \mathrm{p}<0.001$ vs Basal. A significant effect $[\mathrm{F}=12.38 ; \mathrm{p}<0.0001]$ was found across the pretreatment groups with planned comparisons indicating the following differences in $+100 \mathrm{nM}$ UCN2 stimulation: ${ }^{b} \mathrm{p}<0.01$ vs. Control; ${ }^{c} \mathrm{p}<0.001$ vs. H89. This data was replicated in three independent experiments. (B) Effect of PKA activators on UCN 2-stimulated cyclic AMP accumulation. After Y79 cells ( $n=13 /$ group) were pretreated for 1 h with dibutyryl-cyclic AMP (dbcAMP) (4 mM) or the Sp-isomer of adenosine-3',5'-cyclic AMP monophosphorothioate (Sp-cAMPS) $(500 \mu \mathrm{M})$ to maximally activate PKA, they were incubated with buffer or stimulated with $100 \mathrm{nM} \mathrm{UCN} 2$ for $15 \mathrm{~min}$. By ANOVA, a significant within (but not across) pretreatment group effect $[\mathrm{F}=676.5 ; \mathrm{p}<0.0001]$ was found with planned comparisons indicating the following: ${ }^{\mathrm{a}} \mathrm{p}<0.001 \mathrm{vs}$. Control. These findings were replicated in two independent experiments. (C) Effect of casein kinase (CK) inhibition 
on UCN2-induced $\mathrm{CRF}_{2(\mathrm{a})}$ receptor desensitization. $\mathrm{Y} 79$ cells were incubated for $30 \mathrm{~min}$ with media (Control) or CK inhibitors TBB $(20 \mu \mathrm{M})$, Quinalizarin $(20 \mu \mathrm{M})$ or IC261 (100 $\mu \mathrm{M}$ ). After these cells were further pretreated with media or $100 \mathrm{nM} \mathrm{UCN} 2$ for $15 \mathrm{~min}$ (to desensitize $\mathrm{CRF}_{2(\mathrm{a})}$ receptors) in the continuing presence of $\mathrm{CK}$ inhibitors, they were incubated with buffer or stimulated with $100 \mathrm{nM}$ UCN2 for $15 \mathrm{~min}$. By ANOVA, there was only a significant within group (Control and CK Inhibitor) difference [F=62.98, $p<0.0001]$ with planned comparisons indicating the following: ${ }^{\mathrm{a}} \mathrm{p}<0.001 \mathrm{vs}$. Control. Data (\% control mean \pm SEM) were replicated in two independent experiments ( $n=6-10 /$ group). (D) Role of PKA or casein kinase in $\mathrm{CRF}_{2(\mathrm{a})}$ receptor phosphorylation. After cells were pretreated for 30 min with a PKA inhibitor ( $2 \mu \mathrm{M}$ H89 or $100 \mu \mathrm{M}$ RpcAMP) or a CK inhibitor (TBB 20 $\mu \mathrm{M})$, they stimulated with $100 \mathrm{nM} \mathrm{UCN} 2$ for $10 \mathrm{~min}$. Cell were also incubated with only dbcAMP (4 mM for $10 \mathrm{~min}$ ) to activate PKA. $\mathrm{CRF}_{2(\mathrm{a})}$ receptor phosphorylation was then quantitated (see Methods). This data was replicated in a separate experiment. 
A.

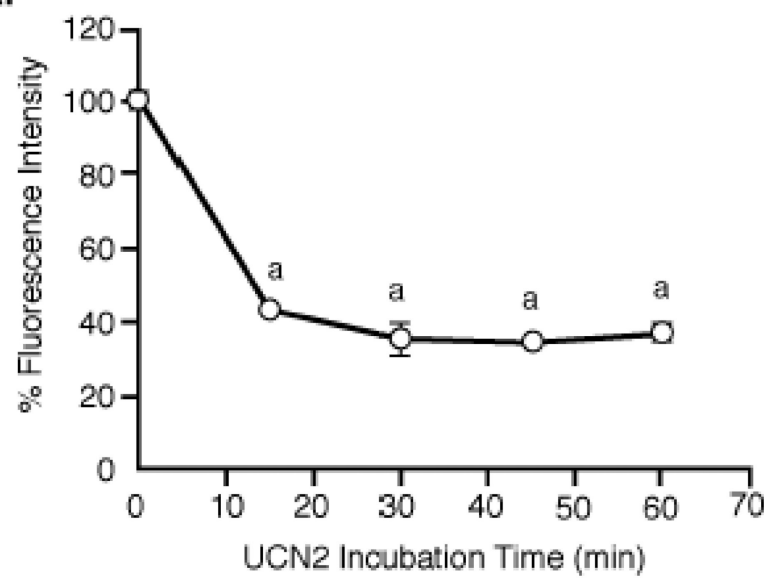

B.

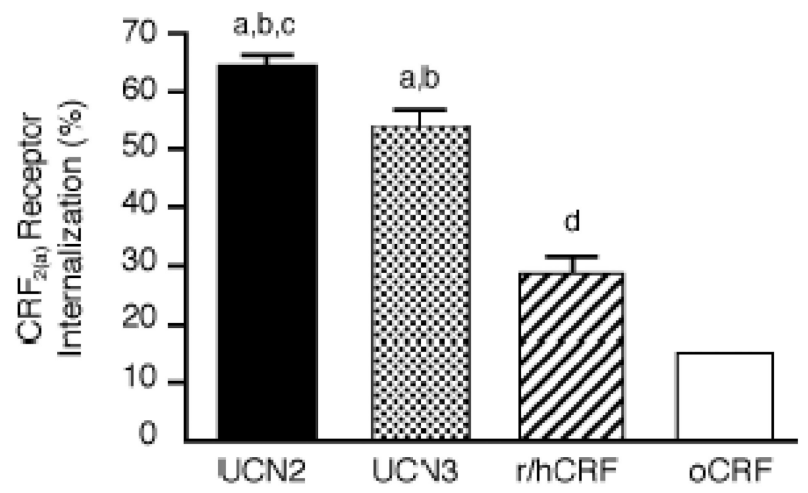

c.

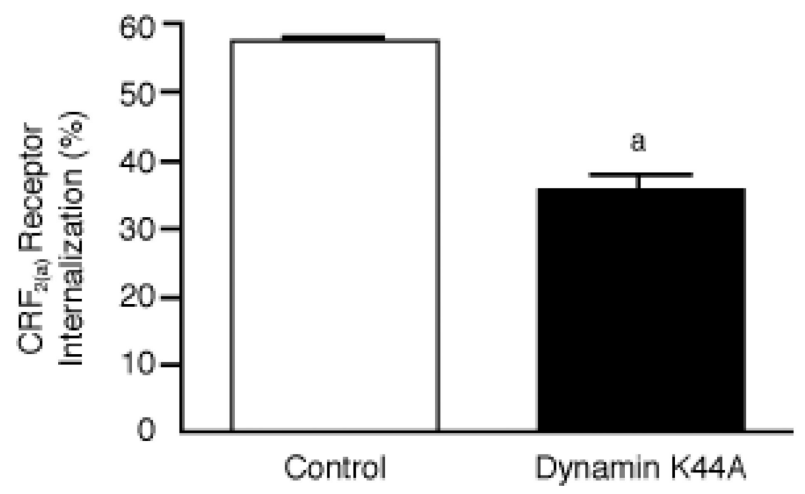

Figure 9. Agonist-stimulated $\mathrm{CRF}_{2}$ (a) receptor internalization in $\mathrm{HEK} 293$ cells

(A) Flow cytometry was used to measure the time course for internalization of HA-tagged $\mathrm{CRF}_{2(\mathrm{a})}$ receptors in HEK293 cells transfected $72 \mathrm{~h}$ earlier and then incubated with $100 \mathrm{nM}$ UCN2 for 0-60 min ( $n=2-4 /$ timepoint). By ANOVA, there were significant differences across the timepoint groups $[\mathrm{F}=429.2 ; \mathrm{p}<0.0001]$ with planned comparisons indicating the following: ${ }^{a} \mathrm{p}<0.001$ vs $0 \mathrm{~min}$. This data was confirmed in five independent experiments. (B) $\mathrm{CRF}_{2(\mathrm{a})}$ receptor internalization was measured in transfected HEK293 stimulated for 30 min with $100 \mathrm{nM}$ UCN2, UCN3, r/hCRF, or oCRF (n=2-3/group). By ANOVA, there were significant differences across the agonist stimulation groups $[\mathrm{F}=56.65 ; \mathrm{p}<0.0001]$ with planned indicating the following: ${ }^{\mathrm{a}} \mathrm{p}<0.001 \mathrm{vs}$ oCRF; ${ }^{\mathrm{b}} \mathrm{p}<0.001 \mathrm{vs} \mathrm{r} / \mathrm{hCRF} ;{ }^{\mathrm{c}} \mathrm{p}<0.05 \mathrm{vs}$ 
UCN3; ${ }^{\mathrm{d}}<<0.05$ vs oCRF. This data was confirmed in three independent experiments. (C)

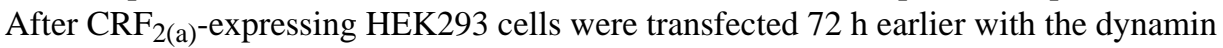
dominant negative mutant $\mathrm{K} 44 \mathrm{~A}$ or empty vector, $\mathrm{CRF}_{2(\mathrm{a})}$ receptor internalization was measured by flow cytometry following a 30-min stimulation with $100 \mathrm{nM} \mathrm{UCN} 2(\mathrm{n}=2 /$ group). By t-test, the groups were statistically different: ${ }^{\mathrm{a}} \mathrm{p}<0.0001$ vs Control. These results were replicated in four independent experiments. Vasopressin V2 receptor internalization in V2-expressing HEK293 cells incubated with $100 \mathrm{nM}$ arginine vasopressin for $30 \mathrm{~min}$ was also significantly decreased $(\mathrm{p}=0.02)$ by dynamin $\mathrm{K} 44 \mathrm{~A}(29.8 \pm 3.7 \%)$ compared to control vector $(50.0 \pm 0.2 \%)$. 

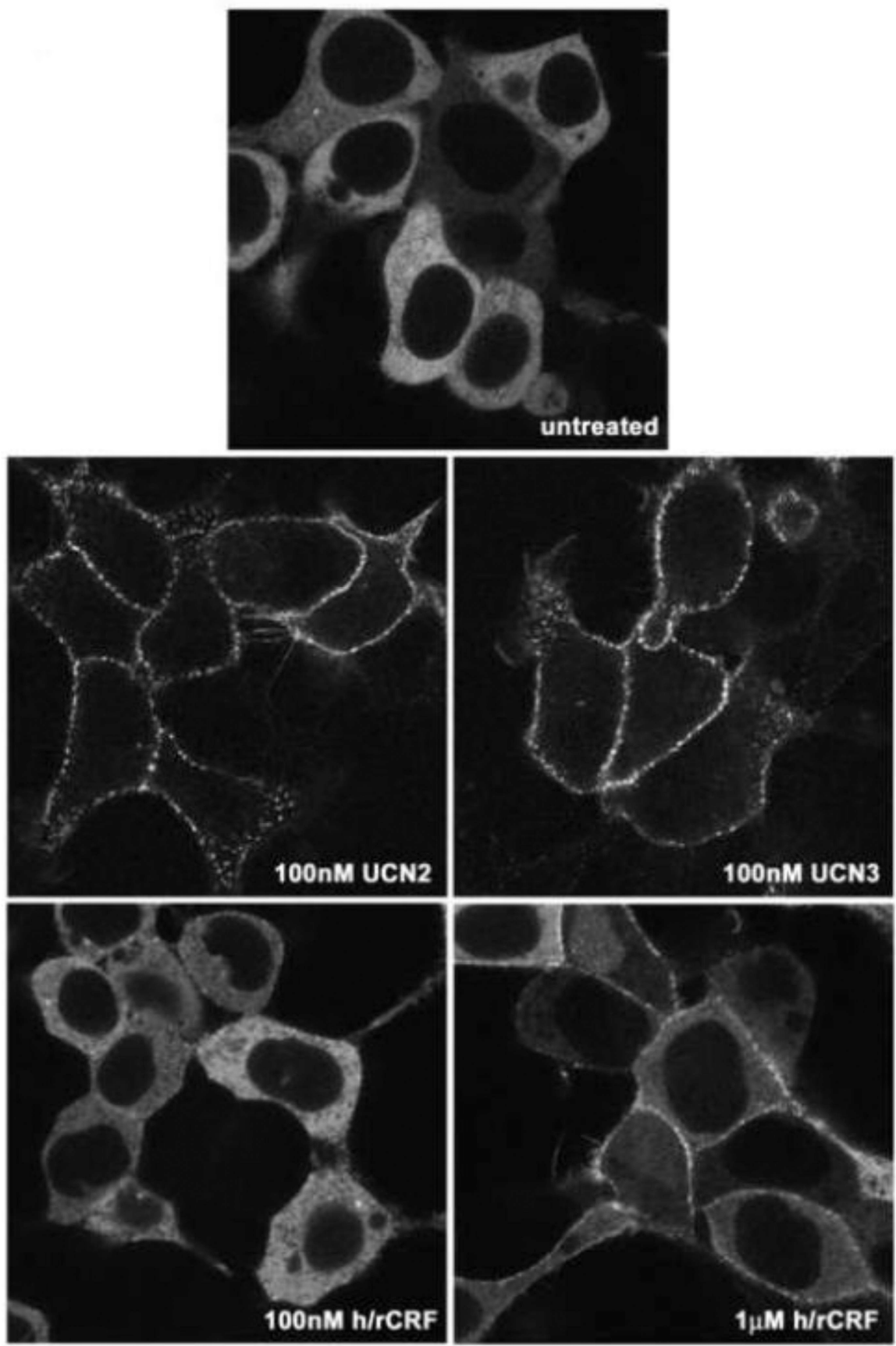

Figure 10. Recruitment of $\beta$ arrestin2 by agonist-activated human $\mathrm{CRF}_{2}$ (a) receptors in HEK293 cells

Confocal microscopy was used to evaluate the interaction of ßarrestin2-GFP with full-length wild-type $\mathrm{CRF}_{2(\mathrm{a})}$ receptors transiently expressed in HEK293 cells. This representative experiment shows the distribution of $\beta$ arrestin2-GFP in untreated cells and cells incubated with UCN2 $(100 \mathrm{nM})$, UCN3 $(100 \mathrm{nM})$, or r/hCRF $(100 \mathrm{nM}$ or $1 \mu \mathrm{M})$ for approximately 10 $\min$. 

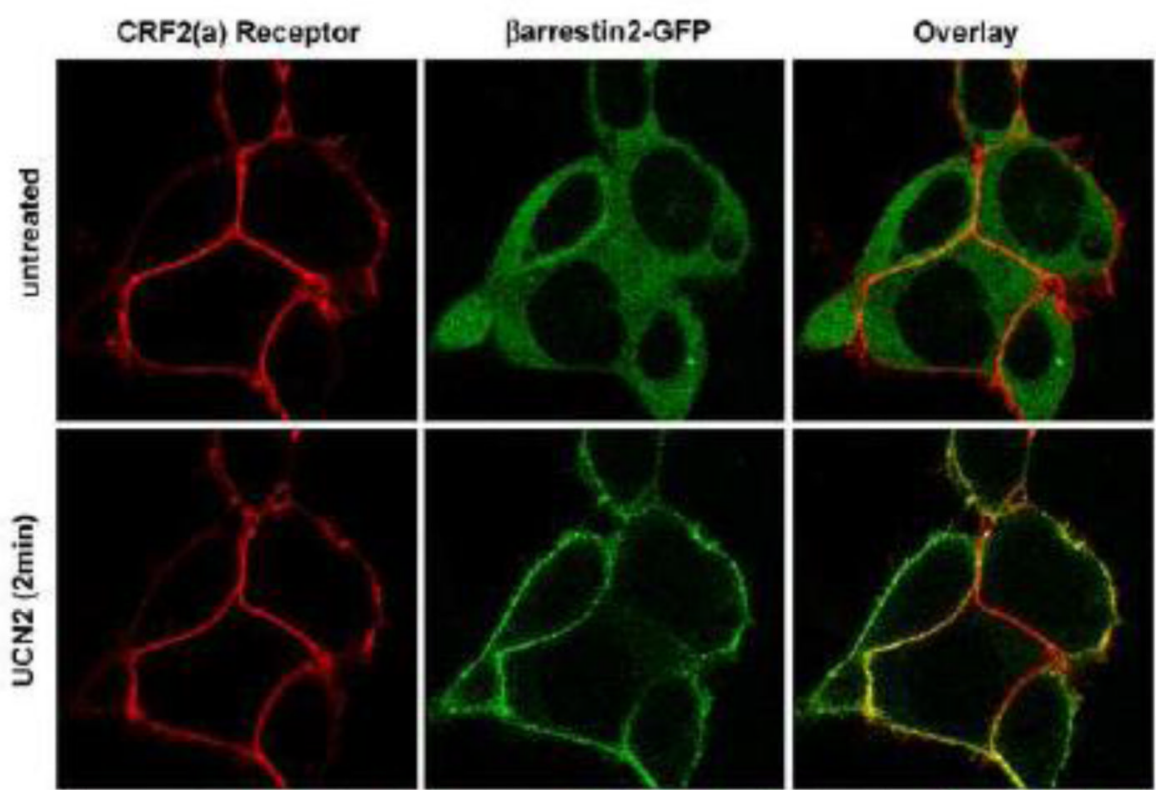

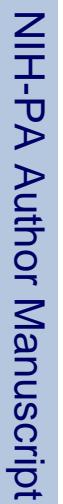
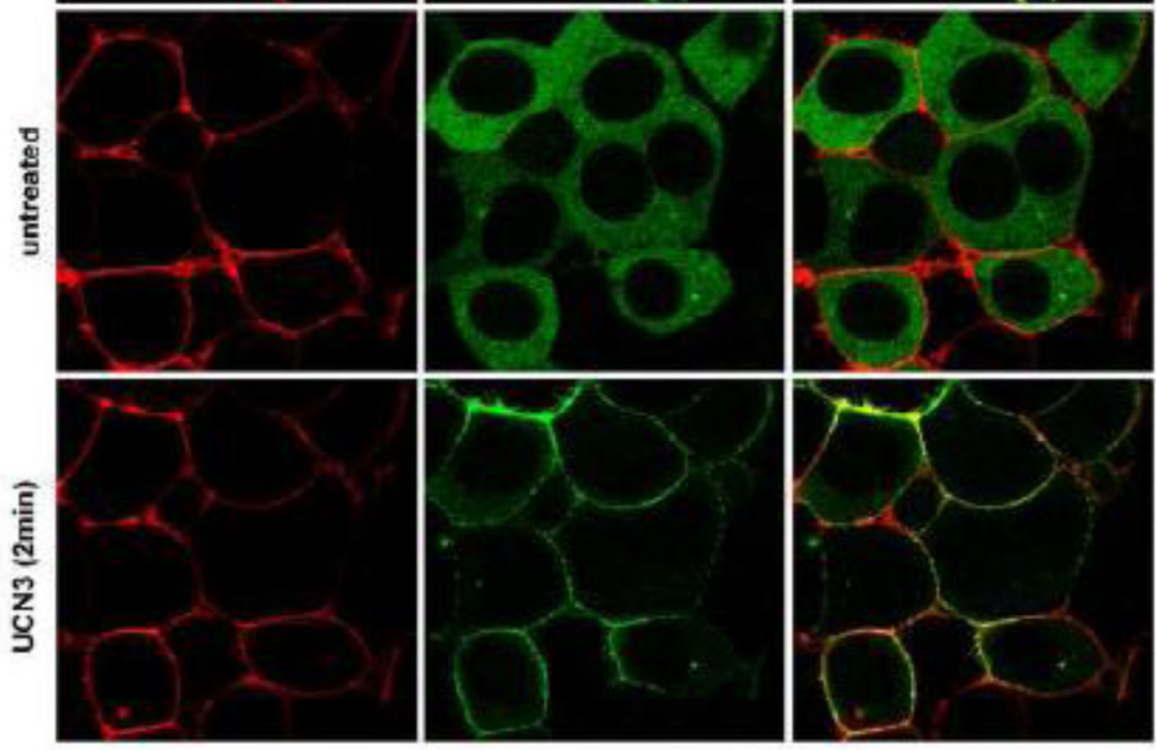

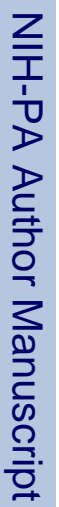

A 


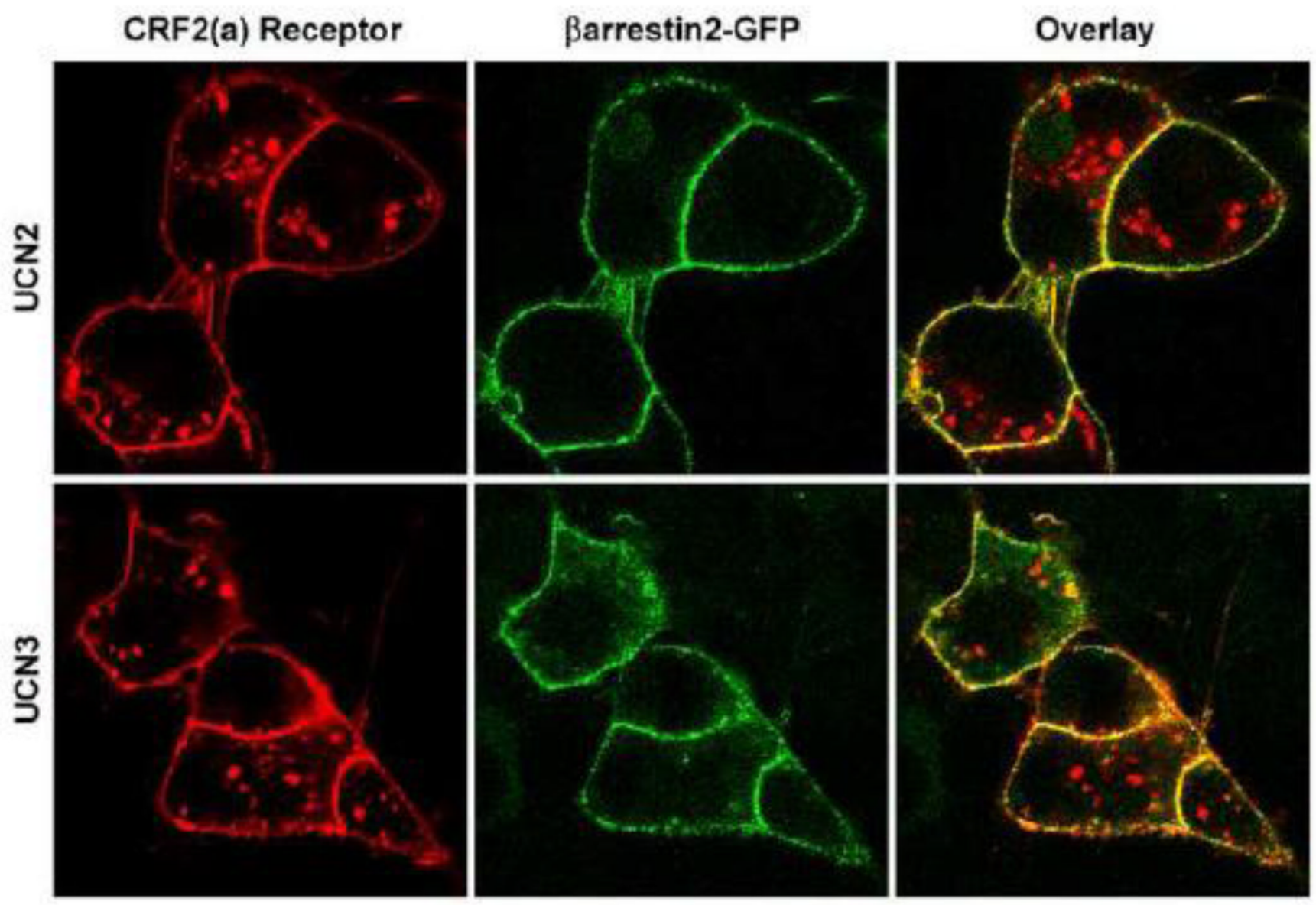

B

Figure 11. Colocalization of $\beta$ arrestin2 with cell-surface but not internalized agonist-activated $\mathrm{CRF}_{2(\mathbf{a})}$ receptors

HEK293 cells transiently expressing $\beta$ arrestin2-GFP and $\mathrm{HA}-\mathrm{CRF}_{2(\mathrm{a})}$ receptors were prelabeled with Alexa Fluor 594 conjugated anti-HA monoclonal antibody and evaluated by confocal microscopy. (A) Distribution of $\mathrm{CRF}_{2 \text { (a) }}$ receptor immunofluorescence (red) and $\beta$ arrestin2-GFP fluorescence (green) in the same cells before and after a 2 min treatment with $100 \mathrm{nM} \mathrm{UCN} 2$ or UCN3. (B) Distribution of $\mathrm{CRF}_{2(\mathrm{a})}$ receptor immunofluorescence (red) and $\beta$ arrestin2-GFP fluorescence (green) after an $\sim 30$ min treatment with $100 \mathrm{nM}$ $\mathrm{UCN} 2$ or UCN3. Colocalization of $\beta$ arrestin2-GFP with the receptor is indicated by the yellow color in the overlay. 


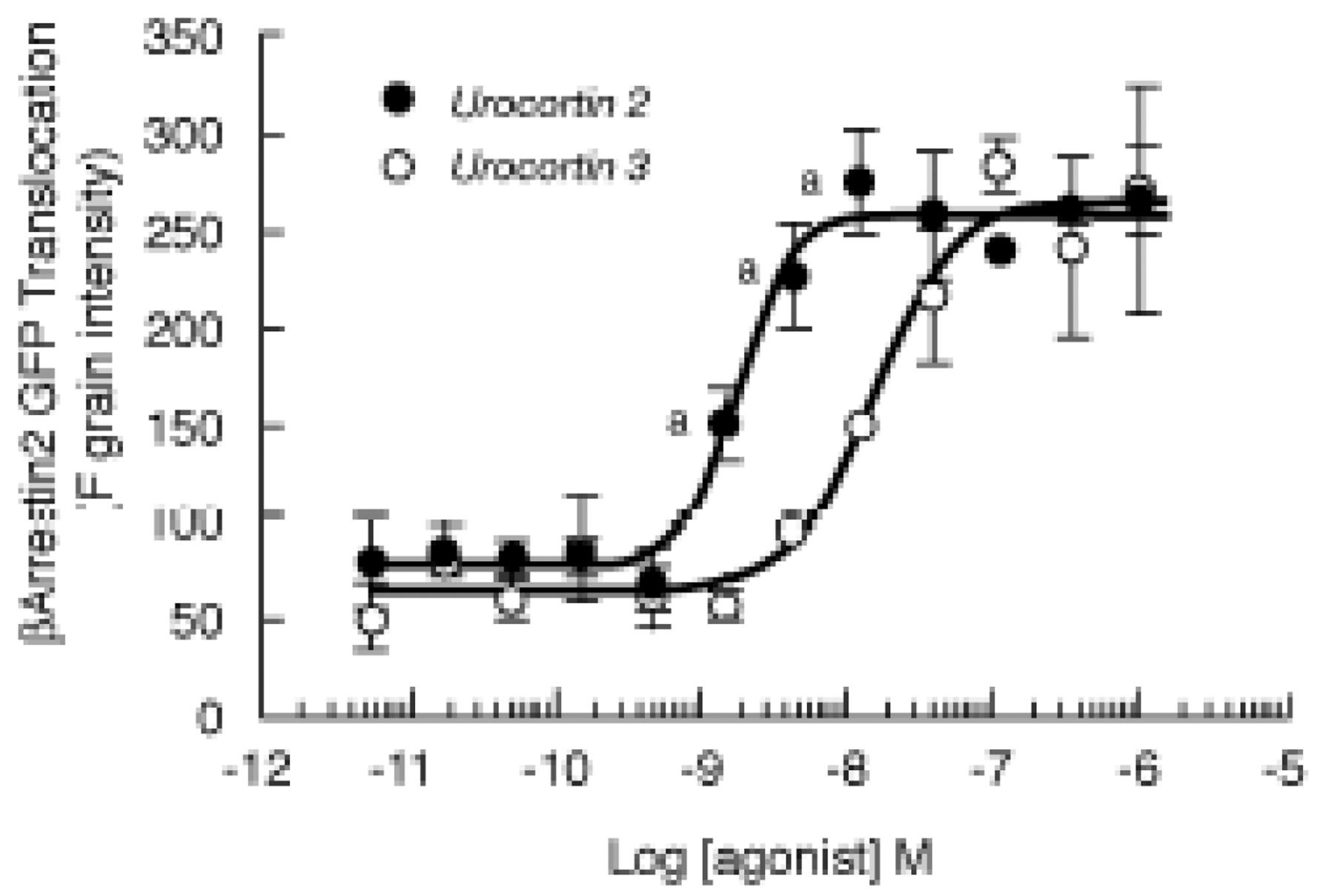

Figure 12. Quantitation of $\beta$ arrestin2 translocation to the agonist-activated $\mathrm{CRF}_{2}$ (a) receptors in U2OS cells

U2OS cells transiently co-expressing $\beta$ arrestin2-GFP and full-length wild-type human $\mathrm{CRF}_{2(\mathrm{a})}$ receptors were plated in 96-well plates and cultured overnight. Cells were then stimulated with urocortin 2 or urocortin $3(0-1000 \mathrm{nM})$ for $30 \mathrm{~min}$ and analyzed on the INCell Analyzer 3000. The reported parameter "Fgrains" represents the fluorescence intensity of $\beta$ arrestin2-GFP localized with the receptor in spots or grains at the plasma membrane. Data represent the mean \pm SEM for 3 independent experiments performed in triplicate. By ANOVA, there was a significant interaction $[F=10.50 ; p<0.0001]$ for the urocortin group (UCN2, UCN3) and stimulation concentrations $\left(10^{-11}\right.$ to $10^{-6} \mathrm{M}$ agonist). A significant within group effect $[\mathrm{F}=78.49 ; \mathrm{p}<0.0001]$ was found with planned comparisons indicating significant increases in $\beta$ Arrrestin 2 translocation over the agonist concentration range for both urocortins. A significant across pretreatment group effect $[\mathrm{F}=23.80 ; \mathrm{p}<0.05]$ was detected with planned comparisons indicating the following: ${ }^{a} \mathrm{p}<0.001 \mathrm{vs}$ UCN3. 


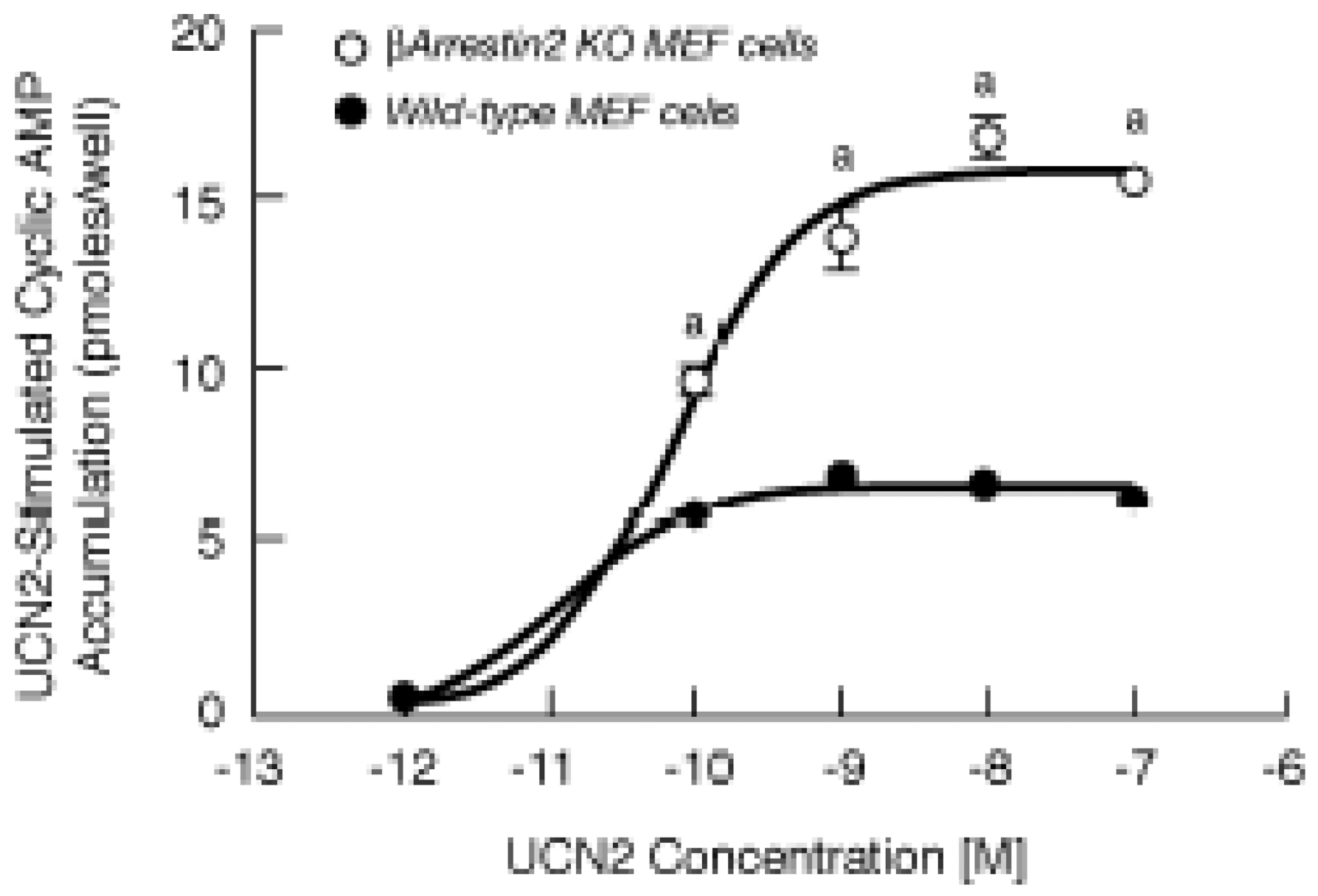

Figure 13. Dose-response stimulation of cyclic AMP accumulation by urocortin 2 in wild-type and ßarrestin2 knockout mouse embryonic fibroblast (MEF) cells

In two experiments, cyclic AMP levels (pmoles/well) were measured in quadruplicate in $\mathrm{CRF}_{2(\mathrm{a})}$ receptor-expressing MEF cells stimulated with 0-100 nM UCN2 for $15 \mathrm{~min}$. By ANOVA, there was a significant interaction $[\mathrm{F}=50.13 ; \mathrm{p}<0.0001]$ for MEF cell group and stimulation conditions $\left(10^{-12}\right.$ to $\left.10^{-7} \mathrm{M} \mathrm{UCN} 2\right)$. A significant within group effect $[\mathrm{F}=251.9$; $\mathrm{p}<0.0001]$ was observed with planned comparisons indicating significant increases in cyclic AMP accumulation over the UCN2 concentration range. A significant across MEF cell group effect $[\mathrm{F}=534.7 ; \mathrm{p}<0.0001]$ was detected with planned comparisons indicating the following difference: ${ }^{\mathrm{a}} \mathrm{p}<0.001$ vs Wild-type MEF cells. 